\title{
AN OPEN DOOR TO ENDING EXPLOITATION: ACCOUNTABILITY FOR VIOLATIONS OF INFORMED CONSENT UNDER THE ALIEN TORT STATUTE
}

\author{
ERIN TALATI $^{\dagger}$
}

INTRODUCTION

I. Clinical Trials Move Abroad—But Human Subjects

PROTECTIONS Do Not Follow

A. Utility of Extraterritorial Research to Multinational Corporations......236

B. Utility of Medical Research to Developing Countries. .241

C. Inadequate Enforcement of an Informed Consent Requirement Permits Exploitation.

II. Human Subjects CAN ENFORCE Protections Under THE ATS

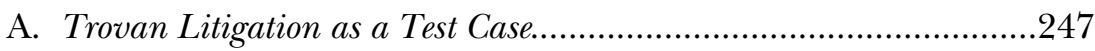

B. Judicial Interpretation of the ATS Leaves Room for Expansion of the Federal Common Law ..............................................................248

1. Historical Perspective on the ATS .........................................250

2. Filartiga and Tel-Oren.........................................................252

3. The Sosa Standard Defined: A Jurisdictional Statute Recognizing Federal Common Law .254

III. INFORMED CONSENT MEETS THE SOSA STANDARD FOR A NORM OF CUSTOMARY INTERNATIONAL LAW .255

A. Human Subjects Protections Require Informed Consent.....

1. Nuremberg Code. .257

2. Declaration of Helsinki .259

3. CIOMS International Ethical Guidelines for Research Involving Human Subjects

${ }^{\dagger}$ B.A. 2001, Northwestern University; J.D./M.D./Masters of Bioethics Candidate 2007, University of Pennsylvania. I would like to thank Professors Stephen Burbank and Kristin Madison for their insightful comments through multiple drafts of this Comment. I would also like to thank Professors Eric Feldman and Art Caplan for their assistance and encouragement in developing a topic. I am grateful for the skillful editing of the Associate and Senior Editors of the University of Pennsylvania Law Review and especially to Michelle Peters, Karyn Brudnicki, and Stephanie Hales for their thoughtful suggestions. Lastly, I would like to thank my family for their support and for giving me space to write during the little time I was home with them. All opinions and errors are my own. 
4. International Conference on Harmonisation: Good Clinical Practices . .263

5. United Nations Provisions.............................................263

6. Convention on Human Rights and Biomedicine ..................264

B. Informed Consent Is Universal, Definable, and Obligatory ................265

1. The Mandate for Informed Consent is Universal ..................266

2. Informed Consent is Definable ........................................268

3. The Norm of Informed Consent is Obligatory .....................268

C. A Norm of Informed Consent Should Be Recognized Under the Federal Common Law ................................................................269

D. Nonsubstantive Considerations in ATS Litigation .........................271

1. State Action Requirement..............................................271

2. Forum Non Conveniens ............................................... 274

3. Political Question Doctrine ..........................................275

4. Evidentiary Burdens ....................................................2276

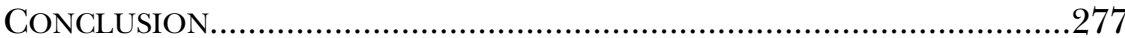

\section{INTRODUCTION}

In 1914 a New York court decided the seminal case that established an individual's right to informed consent. ${ }^{1}$ The court opined that "[e]very human being of adult years and sound mind has a right to determine what shall be done with his own body." Almost a century later, however, a New York court effectively denied enforcement of that right to every human being outside of the United States when it declined to find jurisdiction under the Alien Tort Statute for a foreign violation of informed consent. ${ }^{3}$ A 2005 film, The Constant Gardener, heightened public awareness of international violations of informed consent by exposing questionable tuberculosis experiments conducted on nonconsenting, HIV-infected patients in Africa and revealing the inability of these patients to escape experimentation in clinical trials if they wished to maintain later access to basic medical care. ${ }^{4}$ With an increased demand for clinical trials to support the appropri-

${ }^{1}$ Schloendorff v. Soc'y of N.Y. Hosp., 105 N.E. 92 (N.Y. 1914), overruled on other grounds by Bing v. Thunig, 143 N.E.2d 3, 9 (N.Y. 1957).

${ }^{2}$ Id. at 93 (emphasis added).

${ }^{3}$ See infra Part II.A (discussing the Trovan Case, in which a New York court dismissed the claims of Nigerian clinical trial participants under the Alien Tort Statute, finding that it lacked a sufficient basis to evaluate the alleged harms suffered by the plaintiffs).

${ }^{4}$ THE CONSTANT GaRdener (Focus Features 2005). 
ateness of drugs, the number of clinical trials in developing countries ${ }^{5}$ is likely to increase. ${ }^{6}$ The above examples demonstrate the particular vulnerability of human subjects in developing countries, and the need for more rigorous protection of their rights in the international context.

Notwithstanding recent circumstances in both fact and film, international consensus demands certain minimum protections for human subjects involved in research and considers deviation from those protections to be violations of human rights. Several international instruments describe protections for human subjects involved in clinical trials. These instruments, however, provide no formal remedy for harms resulting from a breach of the universal principles governing research ethics, including the right to informed consent. Some individual countries have attempted to formalize protections through regulatory measures designed to incentivize conduct consistent with the mandates of ethically acceptable research. ${ }^{7}$ Yet inconsistent or nonexistent enforcement of these measures again leaves human subjects without any real protection. The inadequacy of judicial standards and regulatory enforcement in many developing countries has prompted human research participants to explore other means of enforcing their right to informed consent.

\footnotetext{
${ }^{5}$ This Comment does not attempt to provide an official definition of the term "developing country," as the term is used with variable definitions within the legal, medical, and ethical literature. Instead, this Comment uses the terms "developing country," "developing nation," "third world country," and "third world nation" interchangeably. Each term includes those countries that, due to low incomes and marked lack of access to medical attention and treatment options, are dominantly populated by individuals vulnerable to exploitation in the context of human subject research. Such countries may fall under the low- and middle-income categories of traditional classifications. See The World Bank, Country Classification, http://www.worldbank.org (follow "Countries" hyperlink; then follow "Data" hyperlink; then follow "Country Classification” hyperlink) (last visited Oct. 22, 2006) (defining groups of countries according to gross national income per capita).

${ }^{6}$ See infra Part I.A-B (discussing incentives for conducting clinical research in developing countries).

See infra Part III.A (describing regulations promulgated by Nuremberg Tribunals, the World Medical Association, the Council for International Organizations of Medical Sciences, and the International Conference on Harmonisation).
} 
The Alien Tort Statute (ATS) ${ }^{8}$ provides a viable option for these individuals, although it has not yet been successfully employed for such a purpose. ${ }^{9}$ This Comment argues that the ATS, in fact, provides the most promising remedy for an individual whose right to informed consent has been violated in a clinical trial conducted in a developing country. While there are significant barriers to succeeding on any ATS claim, these barriers are not unique to the situation considered here and should not preclude a plaintiff from bringing an action under the ATS.

Part I examines the increasing globalization of clinical trials, and the need to protect human participants in these research endeavors. Part II describes the ATS and explores its reach over international torts after the U.S. Supreme Court's decision in Sosa v. AlvarezMachain in 2004. ${ }^{10}$ This decision restrained the growing applicability of the ATS to novel situations involving violations of human rights. Specifically, the Sosa Court addressed whether the ATS provided only a jurisdictional basis for a suit in a U.S. federal court or, more broadly, whether it permitted courts to establish a new cause of action for violations of international law. ${ }^{11}$ In deciding that the statute conferred jurisdiction only, the Sosa decision has been read to sharply limit any

\footnotetext{
${ }^{8}$ Alien's Action for Tort, 28 U.S.C. $\$ 1350$ (2000) (providing that " $[\mathrm{t}]$ he district courts shall have original jurisdiction of any civil action by an alien for a tort only, committed in violation of the law of nations or by a treaty of the United States"). The legal literature refers to this law as either the Alien Tort Statute (ATS) or the Alien Tort Claims Act (ATCA). This Comment uses Alien Tort Statute and ATS for the remainder of the discussion.

${ }^{9}$ Because this Comment examines the viability of remedy under the ATS in United States courts, it focuses on the United States as the "developed nation," in contrast to the "developing nation" in which research may be conducted. This does not necessarily mean that the United States has the most developed or protective standards for human subjects, or that no developing country offers protection to human subjects. Furthermore, in focusing this discussion on the viability of a legal remedy under the ATS, this Comment specifically discusses recognition of the norm of informed consent. This is not to suggest that informed consent is the only ethical norm that merits concern in conducting international research. Certainly the potential for subject exploitation and unfair practices may arise in many aspects of international research, such as negotiating post-trial access to promising remedies for illness. The focus remains on informed consent because it is so strongly regarded as an imperative in any human subjects research that it fulfills the specificity required for an actionable violation under the ATS. See infra Part III.B-C (discussing informed consent as an element of customary international law).

542 U.S. 692 (2004)

${ }^{11}$ See id. at 712 (stating that, in Sosa, the respondent, Alvarez-Machain, challenged the claim that the ATS "does no more than vest federal courts with jurisdiction, neither creating nor authorizing the courts to recognize any particular right of action").
} 
claims brought under it that would expand the statute's original applicability. ${ }^{12}$ However, the Court left room for application to a limited body of judge-made federal common law that met the standard set by Sosa. Part III discusses in detail the international law that governs the conduct of clinical trials. It illustrates the intended breadth of international human subjects protections and asserts that, despite variation in approaches, the principle of informed consent emerges from these protections as a universally accepted prerequisite for human subject participation in ethically acceptable medical experimentation. ${ }^{13}$ This Comment concludes that such substantial and consistent international consensus demanding informed consent in the context of medical experimentation raises the status of the doctrine to a norm of customary international law. Because the Sosa decision leaves room for recognition of such norms under the federal common law, violations of informed consent remain actionable under the ATS, even in the restrictive post-Sosa period.

\section{Clinical Trials Move Abroad—But Human Subjects PROTECTIONS DO NOT FOLLOW}

The number of clinical trials conducted abroad continues to rise. ${ }^{14}$ The Food and Drug Administration (FDA) "oversees significantly more foreign research than it did 10 years ago"; ${ }^{15}$ however, the "FDA cannot assure the same level of human subject protections in foreign trials as domestic ones." ${ }^{16}$ The lack of FDA oversight over foreign trials may in fact explain the movement of clinical trials to for-

\footnotetext{
${ }^{12}$ See generally, Eugene Kontorovich, Implementing Sosa v. Alvarez-Machain: What Piracy Reveals About the Limits of the Alien Tort Statute, 80 NOTRE DAME L. REV. 111, 11518 (2004) (arguing that the Supreme Court essentially shut down ATS litigation with the Sosa decision).

${ }^{13}$ See infra Part III.A (describing the doctrine of informed consent and detailing the references to it in various international instruments).

${ }^{14}$ See OfFice Of InSPECTOR Gen., DeP'T OF Health \& Human SERvS., The Globalization of Clinical Trials: A Growing Challenge in Protecting Human SubJECTS 6 (2001) [hereinafter OIG GLOBALIZATION REPORT] (noting that the "number of foreign clinical investigators conducting drug research under Investigational New Drug Applications increased 16-fold" from 1990-1999); see also Ileana DominguezUrban, Harmonization in the Regulation of Pharmaceutical Research and Human Rights: The Need to Think Globally, 30 CORNELL INT'L L.J. 245, 264 (1997) (discussing the FDA's allowance of foreign clinical data as support for new U.S. drug applications under certain circumstances, and suggesting that this circumstance has contributed to the rising number of foreign clinical trials).

${ }^{15}$ OIG GLOBALIZATION REPORT, supra note 14 , at 6.

${ }^{16} I d$. at 12.
} 
eign locations. The FDA implemented a change in its rules in 1994, permitting foreign research data to support applications for the approval of new drugs in the United States. ${ }^{17}$ The number of clinical trials began increasing dramatically, as researchers now could utilize a previously untapped resource-research subjects abroad. Under the regulations,

[a]n application based solely on foreign clinical data meeting U.S. crite-
ria for marketing approval may be approved if: (1) The foreign data are
applicable to the U.S. population and U.S. medical practice; (2) the
studies have been performed by clinical investigators of recognized
competence; and (3) the data may be considered valid without the need for an
on-site inspection by FDA ... 18

Through this amendment, the FDA specifically required investigators to have the capacity to certify the validity of foreign data without direct FDA oversight to support a U.S. drug application. The amended regulations also implied that the FDA would rely on data that it had not itself monitored. The increase in the number of foreign trials thus appears to be one result of, or is at least facilitated by, a move toward relaxed standards for the acceptance of foreign data. The significant benefits attached to conducting trials in developing countries continue to lead to an increasing amount of research conducted abroad. ${ }^{19}$ Absent FDA oversight, however, as more trials move out of the United States-and away from domestic protections for human subjects- the lack of global enforcement of human subjects protections becomes more problematic.

\section{A. Utility of Extraterritorial Research to Multinational Corporations}

Multinational corporations have many reasons to conduct clinical trials in developing countries. ${ }^{20}$ The majority of research done in de-

${ }^{17} 21$ C.F.R. § 314.106(b) (1) (1994); see also William DuBois, Note, New Drug Research, The Extraterritorial Application of FDA Regulations, and the Need for International Cooperation, 36 VAND. J. TRANSNAT'L L. 161, 167 (2003) (commenting on how these 1994 amendments "liberalized" the FDA rules regarding foreign data).

1821 C.F.R. $\$ 314.106$ (b) (2005) (emphasis added).

19 See Ruth MaCKlin, Double STANDARDS In MEDICAL RESEARCH IN DEvEloping COUNTRIES 6-9 (2004) (enumerating both scientific and financial benefits of researching abroad).

${ }^{20}$ This discussion focuses predominantly on research conducted by the private sector, and specifically by multinational corporations, because they are the largest category of investigators conducting foreign research. Focusing on private sector research also permits a more rigorous analysis of the state action requirement under the 
veloping countries typically aims to expand knowledge about a drug. Corporations then can use this knowledge to generate gains not intended for developing countries. ${ }^{21}$ One industry researcher stated that "doing clinical trials in the third world sometimes may be motivated by a variety of reasons. In general, the [primary reasons are] access to the patient in large numbers and [at] a faster rate. And sometimes the third argument, nevertheless, is also at a cheaper price." ${ }^{22}$ This explanation reflects two general categories of factors motivating researchers abroad: study validity (by expanding the size and diversity of the study population) and reduced cost (often by removing regulations imposed by developed countries). ${ }^{23}$

Researchers receive several study-related benefits from conducting clinical trials in developing nations. Investigators can conduct research on diseases and populations that are more diverse than those to which they have access in the United States. ${ }^{24}$ In addition, because individuals in many countries lack access to adequate treatment, trials

ATS. The state action element operates to make an ATS violation more difficult for a plaintiff to prove. As a result, if an argument for liability can succeed against a private actor, such as an industry researcher, then recovery against public or expressly state actors logically follows. See infra Part III.D.1 (discussing the state action requirement of the Sosa standard).

${ }^{21}$ Nancy Kass \& Adnan A. Hyder, Attitudes and Experiences of U.S. and Developing Country Investigators Regarding U.S. Human Subjects Regulations, in 2 ETHICAL AND POLICY ISSUES IN INTERNATIONAL RESEARCH: CLINICAL TRIALS IN DEVELOPING COUNTRIES B-1, B-31 to B-32 (2001) (relating responses from members of a focus group, and quoting an unnamed researcher in a pharmaceutical company, who added that "the pharmaceutical industry is a profitable business ... not a charitable business").

${ }^{22} I d$.

${ }^{23}$ Recall that individual developed or developing countries may fall short of or exceed these trends respectively. See supra note 5. Of course, there are additional reasons that motivate researchers to conduct studies abroad; the focus here is on those which increase the vulnerability of participants to violations of human subjects protections.

${ }^{24}$ Many diseases in developing countries have been virtually eradicated in developed countries. By going abroad, investigators are able to see a greater variety of diseases, and can learn about the effectiveness of treatments for those diseases. For example, investigators can learn about drug-resistant forms of diseases that are almost exclusively found in developing countries, such as malaria and tuberculosis. See Medecins SAns Frontieres, Drugs fOr Neglected Diseases Working Group, ADDRESSING THE CRISIS IN RESEARCH AND DEVELOPMENT FOR NEGLECTED DISEASES 1 (2006), http://www.accessmed-msf.org/documents/breifR\&Djan2006.doc (listing these conditions as "neglected" in developing countries, due to lack of access to treatments). Unfortunately, research frequently is lacking for those diseases which do not at all affect wealthier countries. Id. More commonly, research is done in developing countries because, when abroad, investigators can see diseases at a different point in the course of the illness. See infra note 25 and accompanying text. 
may be conducted on large numbers of individuals with conditions that, untreated, have progressed further along in the natural course of the disease. ${ }^{25}$ One industry representative summarized: "You want patients with no other disease states and no other treatments. Then you can say relatively clearly that whatever happens to those patients is from the drug." ${ }^{26}$ Indeed, research on so-called "naïve" subjects ${ }^{27}$ generates more reliable data. Being able to conduct research on such populations also permits investigators to draw conclusions about the effectiveness of a treatment for more severe manifestations of a disease. These conclusions may then be used domestically in a patient who has not sought early treatment for a condition or for whom early treatment has failed. Often, due to a fragile medical state, these individuals would be excluded from domestic trials; in a developing country, however, they may be permitted or even encouraged to enter a trial. Moreover, the access gap ${ }^{28}$ creates an incentive for researchers to do research in developing countries, where they can conduct placebo control trials rather than active control trials on subjects. ${ }^{29}$ The FDA prefers placebo controls, ${ }^{30}$ and the individuals or drug approval

${ }^{25}$ See MACKLIN, supra note 19, at 6-7 (asserting that a major source of research subjects may be found in developing countries where patients are "exposed to fewer other drugs than ... patients in industrialized countries"); see also OIG GLOBALIZATION REPORT, supra note 14, at 8 ("Sponsors report using emerging sites for their research to gain access to large numbers of subjects with a particular disease, especially those that are 'naïve subjects' (i.e., have not been treated for the disease being studied), and to obtain data on different racial or ethnic groups."); Sonia Shah, Globalizing Clinical Research: Big Pharma Tries Out First World Drugs on Unsuspecting Third World Patients, THE NATION, July 1, 2002, at 23, 23-24 (noting that individuals in developing countries frequently are not on medications that could skew the results of a drug trial and therefore can provide better data for researchers).

${ }^{26}$ MACKLIN, supra note 19, at 7 (citing Shah, supra note 25, at 23 (quotation marks omitted)).

${ }^{27}$ See id. (defining untreated subjects as "naïve").

${ }^{28}$ The difference between access to treatment in developing countries and developed countries has been referred to as the "access gap," where effective treatments for a particular condition are known, but not available in a specific area, usually a developing country. See, e.g., Amy Kapczynski et al., Addressing Global Health Inequities: An Open Licensing Approach for University Innovations, 20 BERKELEY TECH. L.J. 1031, 1037 (2005) (defining the "access gap" as "the systematic inability of individuals in developing countries to obtain existing medicines").

${ }^{29}$ In placebo control trials, investigators compare a drug's effectiveness to an inactive preparation of the drug, while in active control trials, the relevant comparison is between the study drug and an active drug that is the known standard of care for a particular condition. See 21 C.F.R. § 314.126(b) (2) (i), (iv) (2005) (defining placebo and active control trials, and identifying each as a valid method of assessing a drug's effect).

${ }^{30}$ See U.S. Dep't of Health \& Human Servs., FDA Comm. for Drug Eval. \& Research, Advanced Scientific Education Seminar Series: The Use of Placebos in Clinical 
entities making determinations about a drug's promise for treating a particular disease more highly prize placebo control trials because they generate more accurate statements about the effectiveness of a drug. ${ }^{31}$ However, such trials often cannot be conducted in developed countries. ${ }^{32}$

The relaxed regulatory environment found in many developing countries also accounts for an increase in clinical trials abroad. ${ }^{33}$ For the multinational corporation, the developing country imposes and enforces fewer affirmative duties to protect research subjects than countries in the developed world. There are two principle reasons for this. First, the policies designed to protect human subjects who participate in clinical trials in a developed country often will not reach investigators' conduct in foreign clinical trials, even if the investigators come from the developed country. ${ }^{34}$ Yet investigators may use data

Trials and the Ethics of the Use of Placebos (Apr. 21, 1999), available at http:// www.fda.gov/cder/foi/special/99/case-trans-42199.txt (suggesting that placebo control trials are the most scientifically valid and thus offer the most rigorous support for a drug's approval).

${ }^{31}$ In addition to the confounding effects that other drugs can have on a study's outcome, the requirement in the United States for active control studies when a disease is treatable also reduces the likelihood that new drugs will be tested in the United States. The U.S. requirement for active control studies may at first appear inconsistent with the FDA's preference for placebo-controlled studies. See supra note 30. Although placebo-controlled trials do offer potentially better data from a scientific standpoint, the FDA recognizes that failure to provide care when a known treatment is available places patients at risk. The requirement for active control trials removes that risk by permitting placebo trials only when no active trial treatment is available. This tension-to obtain the most rigorous data possible on the one hand and to provide active control trials when treatment is available on the other-can lead researchers to seek clinical trial locations outside of the U.S., where such restrictions may not exist. Researchers often select developing countries, typically for one of two reasons: either authorities do not place restrictions on clinical trials or, more commonly, the lack of access to treatment removes the possibility of an active control study.

${ }^{32}$ Placebos may not be used when such use would put the patient at risk. See 21 C.F.R. $\$ 314.126$ (b) (2) (iv) (2005) (noting that an active control should be used when the "administration of placebo ... would be contrary to the interest of the patient"). A known "standard of care" exists when medical providers are aware of an effective treatment for a particular condition. In the United States, the presence of such a known standard of care precludes the use of placebo controls. See Stuart L. Nightingale, Challenges in Human Subject Protection, 50 FOOD \& DRUG L.J. 493, 498 (1995) (describing the appropriate use of placebo controls in trials).

33 See OIG GLOBALIZATION REPORT, supra note 14, at 15 (reporting regulatory deficiencies in foreign oversight).

${ }^{34}$ For example, when United States-based investigators conduct research in foreign countries, guidelines governing domestic research do not extend to their conduct abroad. See id. at 12-16 (discussing the lack of FDA oversight and lack of preparedness of foreign oversight institutions). 
obtained from foreign studies to support a drug application submitted for FDA approval. To obtain FDA approval of a drug and rights for the marketing of that drug in the United States, investigators must submit a New Drug Application (NDA) to the FDA. ${ }^{35}$ With this application, researchers also must submit data from studies which support the NDA. ${ }^{36}$ Acceptable studies include research conducted through one of two approaches. In the first, the private actor chooses initially to file an Investigational New Drug Application (IND) with the FDA, bringing the investigator, regardless of the location of the research, under the federal regulations governing the conduct of research in the United States. ${ }^{37}$ Such research is subject to informed consent provisions applicable to research conducted within the United States itself. $^{38}$ If a private actor chooses not to submit an IND and, consequently, to avoid FDA procedural regulations on its research, in order to have its studies accepted as valid it must meet other ethical guidelines. In this situation, the private actor must abide by either the guidelines specified in the Declaration of Helsinki or the protections provided by regulations in place in the country in which the research is being conducted, whichever option provides greater protection to study participants. ${ }^{39}$

${ }^{35} I d$. at 5 .

${ }^{36} I d$.

${ }^{37} I$. .

${ }^{38}$ See 45 C.F.R. $\$ 46.111$ (2005) (stipulating that "[i]nformed consent will be sought from each prospective subject or the subject's legally authorized representative, in accordance with, and to the extent required by $\S 46.116 . .$. Informed consent will be appropriately documented, in accordance with, and to the extent required by $\S 46.117$ ”); see also Id. $\$ 46.116$ (defining the basic requirements for informed consent); $I d$. $\$ 46.117$ (providing directions for documentation of informed consent).

${ }^{39}$ OIG GLOBALIZATION REPORT, supra note 14, at 5; see also 21 C.F.R. $\S 312.120(5)(c)(1)$ (2005) ("Foreign clinical research is required to have been conducted in accordance with the ethical principles stated in the 'Declaration of Helsinki' ... or the laws and regulations of the country in which the research was conducted, whichever represents the greater protection of the individual."). Federal regulations also note that the "FDA accepts [foreign] studies provided they are well designed, well conducted, performed by qualified investigators, and conducted in accordance with ethical principles acceptable to the world community." 21 C.F.R. $\$ 312.120$ (a) (2005) (emphasis added). The Declaration of Helsinki, by FDA standards, therefore represents the minimum required by the world community. See infra Part III.A.2 (discussing the Declaration of Helsinki's role in the international context). In countries that accept the International Conference on Harmonisation (ICH) Guidelines, those requirements represent the minimum necessary protections, because they are thought to confer stronger protection than the Declaration of Helsinki. See OIG GLOBalization REPORT, supra note 14, at 5 \& $44 \mathrm{n} .11$ (stating that the ICH Guidelines "are more explicit than the Declaration of Helsinki" and therefore are a "higher standard for pro- 
Second, developing countries themselves often provide much less protection to human subjects than developed countries; they therefore lack the infrastructure needed to enforce the more stringent provisions imposed on researchers in developed countries. ${ }^{40}$ This lack of local government oversight permits investigators in developing countries to conduct trials more quickly, and at a lower cost per patientsubject, by removing much of the procedural delay. ${ }^{41}$ Such incentives will continue to drive researchers toward foreign research.

\section{B. Utility of Medical Research to Developing Countries}

Not only do various factors motivate both public and private researchers to pursue foreign research sites, but developing countries also openly welcome foreign researchers. ${ }^{42}$ Inhabitants of developing countries often face epidemics of diseases that are either eradicated or adequately treated in developed countries. ${ }^{43}$ The access gap in many developing countries, however, leaves these inhabitants desperate for an opportunity to obtain medication for their diseases. ${ }^{44}$ These individuals are therefore disproportionately more likely to enroll in clinical trials than individuals in developed countries. The majority cannot afford to purchase the medications known to be effective for treating their conditions, and enrollment in a clinical trial offers the

tecting subjects"). This may reflect a trend toward greater recognition of ICH Guidelines. See infra notes 55, 144 (commenting on shifts to the ICH Guidelines in the United States and in Switzerland).

${ }^{40}$ See Benjamin Mason Meier, International Protection of Persons Undergoing Medical Experimentation: Protecting the Right of Informed Consent, 20 BERKELEY J. INT'L L. 513, 53233 (2002) (asserting that poor countries, specifically many African nations, lack legislative protections for human subjects).

${ }^{41}$ See OIG GLOBALIZATION REPORT, supra note 14, at 8 ("[T] hese sites allow [clinical trial sponsors] to recruit subjects quickly and, therefore, bring their drugs to market faster.”).

${ }^{42}$ See Meier, supra note 40, at 532 ("[T] his legislative vacuum [of medical experimentation regulations in foreign countries] is intentional. While governments of these nations are desperate to bring medical research to their dying populations, their nations cannot afford such research without subsidies from multinational pharmaceutical corporations." (footnote omitted)).

${ }^{43}$ See Nuffield Council on Bioethics, The Ethics of Research Related to HEAlTHCARE IN DEVELOPING COUNTRIES 17 (2002) (explaining that a significant contributing factor to the higher mortality rates in developing countries than in developed countries is the much greater presence of communicable diseases in the developing world).

${ }^{44}$ See Meier, supra note 40, at 532-33 (discussing developing countries' inability to provide research or medical care to their inhabitants without assistance). 
potential to receive treatment or an evaluation without cost to the individual. ${ }^{45}$

Governments in developing countries are also likely to cooperate with investigators, and often their large corporate sponsors, who bring relief to public health crises within the countries' borders. Because of the potential benefits these studies offer, developing countries' governments are generally willing to "rubber stamp" protocols proposed by companies wishing to conduct trials, even though adequate precautions may not really be in place to protect research subjects. ${ }^{46}$

\section{Inadequate Enforcement of an Informed Consent Requirement ${ }^{47}$ Permits Exploitation}

Along with the significant incentives of a diversified and naïve subject population, one of the strongest motivators driving investigators to conduct trials in developing countries remains the lack of competent government or regulatory oversight of their actions. ${ }^{48}$ The regulatory requirements attached to human subjects research conducted within the United States can indeed be overwhelming. These restrictions stop questionable research early in the development process. Although multiple guidelines for research conducted in the international context exist, failure to systematically enforce even minimal standards permits the exploitation of human research subjects in developing nations. For example, a study examining compliance with the "best proven" therapeutic efforts standard of the Declaration of Helsinki found that only sixteen percent of studies satisfied the re-

${ }^{45}$ See Joe Stephens, Where Profits and Lives Hang in Balance, WASH. POST, Dec. 17, 2000, at A1 ("Given their poverty and lack of access to decent medical care,... [h] onestly, did they have a choice?" (quotation marks omitted)).

${ }^{46}$ See Meier supra note 40 at 532-33 (claiming that the lack of protections may result from foreign governments seizing opportunities that offer access to treatments, which the country could not provide in the absence of the clinical trials).

${ }^{47}$ See infra Part III (discussing the applicability of the ATS to informed consent). I want to reemphasize, however, that I do not intend to suggest that lack of informed consent is the only concerning violation of human subjects protection in clinical trials conducted in developing countries. For a review of ethical considerations in conducting trials in developing countries, see generally NUFFIELD COUNCIL ON BIOETHICS, supra note 43; NAT'L BIOETHICS ADVISORY COMM'N, 1 ETHICAL AND POLICY ISSUES IN INTERNATIONAL RESEARCH: Clinical TRIAls in DEveloping COUNTRIES (2001) (summarizing an eighteen-month study by the commission concerning ethical issues in clinical trials conducted abroad).

${ }^{48}$ See supra Part I.A-B (enumerating incentives that motivate investigators to conduct research abroad). 
quirement, ${ }^{49}$ despite the fact that Helsinki represents the minimum standard with respect to international research. ${ }^{50}$ And yet, eighty-one percent of these studies were reviewed by an ethics committee or independent review board. ${ }^{51}$ In theory, the role of an ethics committee or an independent review board includes monitoring for compliance with ethical standards such as the Declaration of Helsinki. The results, then, indicate a disconnect between knowledge of and intent to comply with ethics standards, evidenced by the high percentage of studies with ethics and/or independent review board oversight, and the low rate of actual compliance with minimal standards in the international context, as defined by the Declaration of Helsinki. The study's authors attribute this difference to the belief that investigators and ethics review committees evaluate researchers' ethical performance based on local, rather than international standards of care for treating a disease. ${ }^{52}$ Nevertheless, the trials evaluated in this study created controversy because of their failure to comply with the Declaration of Helsinki, an international standard. ${ }^{53}$ The authors posit that failure to comply with this international standard occurred not because the Declaration lacks authority, but because international documents provide inadequate guidance on the standard of care to offer in resource-poor countries. ${ }^{54}$ The authors therefore imply that the researchers knew of the international standard for "best proven" therapeutic efforts, but gave more weight to the locally available level of care. Arguably, holding researchers accountable for this choice not to comply with international standards may have been appropriate, and even helpful in resolving the uncertainty around the appropriate standard for resource-poor countries. But certainly in the context of

\footnotetext{
${ }^{49}$ David M. Kent et al., Clinical Trials in Sub-Saharan Africa and Established Standards of Care: A Systematic Review of HIV, Tuberculosis, and Malaria Trials, 292 JAMA 237, 239 (2004). The study focused on compliance with the "best proven" therapeutic efforts standard of the Declaration of Helsinki, specifically in the context of HIV treatment, tuberculosis treatment, and malaria prevention. Id. at 237-39.

${ }^{50}$ See supra note 39 (discussing minimum ethical standards for research worldwide).

${ }^{51}$ Kent et al., supra note 49, at 240.

${ }^{52}$ See id. at 240-41 ("A likely explanation for these findings is that investigators who design and conduct these studies, and the ethics committees who review and approve them, consider trial design in the context of the local level of care rather than the international standard of care.").

${ }^{53}$ See id. at 237. ("These trials stimulated intense debate since they appeared to violate guidelines articulated in the Declaration of Helsinki.").

${ }^{54}$ See id. ("Various international guidelines continue to offer conflicting guidance on this issue.").
} 
informed consent, which is a much more consistently and broadly defined ethical principle, accountability would be appropriate, as greater accountability for researchers would instill greater respect for international standards.

Because individuals responsible for clinical trial oversight in developing countries continue to approve studies that give inadequate attention to participants' rights in order to reap the benefits of the country's cooperation, human subjects lack any real protection for their involvement in the research. ${ }^{56}$ In this environment, abuses are prevalent. $^{57}$

Several instruments attempt to enumerate the rights of human subjects involved in research protocols. Of these rights, informed consent offers the most basic protection. ${ }^{58}$ Despite the ubiquitous references to informed consent in ethical guidelines regarding human subjects, numerous violations of the doctrine have been documented. A series of Washington Post articles noted many of these alleged abuses. ${ }^{59}$ One account described procedural inadequacies in the consent process conducted with healthy subjects from Estonia who were

${ }^{55}$ See Peter Lurie \& Sydney M. Wolfe, Comments on the Draft Health and Human Services Inspector General's Report: The Globalization of Clinical Trials (OEI-01-0000190) (July 5, 2001), reprinted in OIG GLOBALIZATION REPORT, supra note 14, app. D at 37, 40-41 (criticizing as weak the FDA's proposed guidelines for increasing compliance with international standards); Meier, supra note 40, at 534 ("Despite this clear adoption of the doctrine of informed consent, [application of this right under] the ICCPR 'is hobbled by weak implementation provisions."') quoting M. Cheriff Bassiouni et al., An Appraisal of Human Experimentation in International Law and Practice: The Need for International Regulation of Human Experimentation, 72 J. CRIM. L. \& CRIMINOLOGY 1597, 1657 (1981))); see also Peter Lurie \& Dirceu B. Greco, Comment, U.S. Exceptionalism Comes to Research Ethics, 365 THE LANCET 1117, 1117-19 (2005) (attacking the FDA proposal to replace the Declaration of Helsinki with the ICH Good Clinical Practices as only a step away from eviscerating "the standard-bearer for international research ethics [particularly] in the developing world"). While Lurie and Greco raise a valid argument regarding the expansive respect for the Declaration of Helsinki, the FDA changes do not necessarily eviscerate the value of Helsinki. See infra note 145 (providing a counterargument to Lurie and Greco's criticism).

${ }^{56}$ See, e.g., MACKLIN, supra note 19, at 150 ("If informed consent is the first safeguard for the protection of human subjects of research, the second is prior review by a properly constituted, independent research ethics committee.").

${ }_{57}$ See, e.g., id. at 150-52 (recounting two cases, both involving research carried out in China, in which ethical violations resulted from a lack of proper oversight).

${ }_{58}^{5}$ See infra Part III.A (describing the element of informed consent and its requirements in multiple ethical guidelines).

${ }^{59}$ See MACKLIN, supra note 19, at 133-36 (recounting these newspaper stories). 
participating in a Swiss study. ${ }^{60}$ A subject commented that he was asked initially to sign a consent form in a language he did not understand; when the consent form was presented in the proper language, no one explained its meaning or made sure he understood its contents. ${ }^{61}$ Another story involved a study in Argentina, in which consent forms allegedly were forged. ${ }^{62}$ In a third study, testing a drug to treat oral cancer in India, an investigative committee documented several problems, including inadequate consent forms. ${ }^{63}$ Subjects had not been properly informed about the study drug's risks and benefits, and they were not told that participation was voluntary. ${ }^{64}$ Many believed they were being treated rather than participating in an experiment. ${ }^{65}$

As these examples demonstrate, the current regulatory framework fails to recognize the imperative of informed consent in human subjects research, leaving investigators little incentive to change exploitive practices. Without enforcement of ethical standards, investigators lack accountability for violations of ethical norms. ${ }^{66}$ "It is probably true that the behavior of profit-making companies will not be changed

${ }^{60}$ Sharon LaFraniere et al., The Dilemma: Submit or Suffer, WASH. POST, Dec. 19, 2000 , at A1.

${ }^{61} I d$.

${ }^{62}$ See Karen DeYoung \& Deborah Nelson, Latin America Is Ripe for Trials, and Fraud: Frantic Pace Could Overwhelm Controls, WASH. POST, Dec. 21, 2000, at A1 (describing violations of the consent process in this study). After a subject in this study died, the family was shown a signed consent form, which they said they did not sign. Id.

${ }^{63}$ See Scientist Sanctioned Over Drug Trial in India, The GazeTte Online, Nov. 26, 2001, http://www.jhu.edu/ gazette/2001/26nov01/26india.html (describing the study and listing ethical abuses by the researcher).

${ }^{64}$ See K.M. Seethi, Clinical Drug Trials: Bioethics Under Siege, 36 ECON. \& POL. WKLY. 3211, 3212 (2001), available at http://www.frontline.in/f11817/18170040.htm (detailing the consent process in this study).

${ }^{65}$ See R. Krishnakumar, Drug Trials and Ethics, 18 FrontLinE: INDIA's NAT'L MAG., Aug. 18-31, 2001, available at http://www.frontline.in/f11817/18170040.htm (explaining subjects' belief that they were receiving treatment). The belief that one is being "treated" rather than participating in research is called the "therapeutic misconception." See MACKLIN, supra note 19, at 131-32 ("[T] he widespread confusion between participating in research investigating new, unproven therapies, on the one hand, and receiving an established, effective treatment for a health-related condition, on the other hand. ... is known as 'the therapeutic misconception." (quoting Paul S. Appelbaum et al., The Therapeutic Misconception: Informed Consent in Psychiatric Research, 5 INT'L J. L. \& PSYCHIATRY 319 passim (1982)); Nancy M. P. King, Experimental Treatment: Oxymoron or Aspiration?, HASTINGS CTR. REP., July-Aug. 1995, at 6 passim). Exploitation on the basis of this misconception is not uncommon. See infra note 142 (describing modifications of ethical guidelines due to the prevalence of this misconception).

${ }^{66}$ See Meier, supra note 40, at 535-36 (advocating a need to "solidify the absolute nature of the right of free and informed consent"). 
by issuing or revising ethical guidelines governing research. But other pressures, including international partnerships, and collaborative efforts, have already begun to change the picture of research and its aftermath in developing countries." ${ }^{, 7}$ While the current environment still leaves human subjects vulnerable to exploitation by investigators who capitalize on relaxed regulatory frameworks in developing countries, it is the enforcement of regulations, and not the regulations themselves, that is lacking. Accountability for violations of fundamental ethical norms promises progress towards the ultimate goal of behavioral reform and compensates those who have been exploited under the current practice.

\section{Human Subjects Can Enforce Protections Under the ATS}

An individual subject's ability to obtain a remedy for violations of ethical norms will vary depending on the regulatory framework in which the research is conducted. ${ }^{68}$ Such litigation may occur in the countries in which the harm occurred. Certain countries, however, may be unable to perform this function adequately. ${ }^{69}$ Meanwhile, the ATS permits subjects of these countries to seek remedy for these violations in United States courts. ${ }^{70}$ This statute, therefore, provides a viable remedy when clinical trials fail to conform to customary international law regarding informed consent.

In 2001, a group of Nigerian plaintiffs attempted to bring suit in New York under the ATS for alleged human subjects research abuses on this new theory of recovery. ${ }^{71}$ These plaintiffs attempted to use the ATS to enforce international standards for research. The initial ruling in this case found the ATS inapplicable to the conduct of research in clinical trials. ${ }^{72}$ Examination of ATS jurisprudence, however, sug-

${ }^{67}$ MACKLIN, supra note 19 , at 31.

${ }^{68}$ See supra Part I.C (commenting on the lack of substantive enforcement of human subjects protections in many countries).

${ }^{69}$ See Meier, supra note 40, at 535-36 ("International prohibitions are crucial to punishing the abuses that cannot be punished by the country in which the physician [or investigator] works.").

${ }^{70}$ See infra Part III.B-C (arguing that the ATS provides a viable outlet for remedy).

${ }^{71}$ Abdullahi v. Pfizer, Inc. (Trovan Case), No. 01 Civ. 8118, 2005 WL 1870811 (S.D.N.Y. Aug. 9, 2005).

${ }^{72}$ See id. at *14 (holding that a cause of action for failure to provide informed consent "would expand customary international law far beyond that contemplated by the ATS"). 
gests that the statute remains a viable tool for those harmed in clinical trials conducted in violation of customary international law.

\section{A. Trovan Litigation as a Test Case}

In the first case to test the ATS's applicability to research conducted in developing countries, a group of Nigerian plaintiffs brought suit on behalf of their children for alleged harms suffered as a result of participation in a clinical trial in Nigeria to test a new antibiotic for meningitis. ${ }^{73}$ Plaintiffs in the Trovan Case claimed violations of international law relating to informed consent. ${ }^{74}$ They alleged that, following an outbreak of bacterial meningitis, measles, and cholera in Kano, Nigeria, the defendant pharmaceutical company established a center to treat victims of meningitis with an experimental antibiotic. ${ }^{75}$ In the course of "treating" victims, the company was conducting a study of a new drug in order to obtain FDA approval for its use in the pediatric population. ${ }^{76}$ Plaintiffs alleged that the company "failed to explain to the children's parents that the proposed treatment was experimental, that they could refuse it, or that other organizations offered more conventional treatments at the same site free of charge." ${ }^{77}$ These failures, they contended, represented actionable violations under the ATS of customary international law regarding informed consent. ${ }^{78}$ The plaintiffs specifically argued that the investigators failed to obtain valid informed consent as required by customary international law, relying on the Nuremberg Code, Declaration of Helsinki, and International Covenant on Civil and Political Rights (ICCPR) for authority. ${ }^{79}$

The United States District Court for the Southern District of New York dismissed the action on the grounds of forum non conveniens. ${ }^{80}$

${ }^{73} I d$. at $* 1-2$

${ }^{74} I d$. at $* 2$.

${ }^{75} I d$. at $* 1$.

${ }^{76} I d$. at $* 2$.

${ }^{77}$ Id. (quoting Abdullahi v. Pfizer, Inc., No. 01 CIV. 8118, 2002 WL 31082956, at *2 (S.D.N.Y. Sept. 17, 2002) (quotation marks omitted)).

${ }^{78} \mathrm{Id}$.

${ }^{79} I d$. at *6 ("Plaintiffs rely on the Nuremberg Code, the Declaration of Helsinki, article 7 of the ICCPR and 'other norms of international law' to frame their complaint.").

${ }^{80} I d$. at *1 (citing the court's initial dismissal of the case in Abdullahi, $2002 \mathrm{WL}$ 31082956). Forum non conveniens challenges remain an obstacle to securing effective relief under the ATS. See infra notes 207-12 and accompanying text for a discussion of procedural barriers once a claim meets substantive ATS requirements. 
On appeal to the Second Circuit Court of Appeals, the case was remanded to determine whether there was a suitable alternative forum. ${ }^{81}$ On remand, the district court dismissed the case for a second time on the grounds of forum non conveniens, but also found that the plaintiffs failed to allege an actionable violation under the ATS. ${ }^{82}$ In its discussion, the court stated that the Supreme Court ruling in Sosa v. Alvarez-Machain ${ }^{83}$ restricted the statute's reach and excluded the claims brought by the plaintiffs. ${ }^{84}$

On the record provided to it, however, the New York district court lacked the information necessary to evaluate the alleged violation under the ATS, given the rigid standard that the U.S. Supreme Court established in Sosa. ${ }^{85}$ To complete a reasoned analysis under Sosa, the court would have to consider whether the specific international standards raised by the plaintiffs individually would permit recovery. If they did not, the court should have considered whether, together, the plaintiffs named a right meeting the Sosa criteria for developing the federal common law. Carefully examined, the holding in Sosa, when applied to the facts in the Trovan Case, would not exclude litigation of the claims alleged. The ATS, in fact, remains an important tool through which courts may create accountability for violations of ethical norms governing human subjects research.

\section{B. Judicial Interpretation of the ATS Leaves Room for Expansion of the Federal Common Law}

The history of the ATS gives context to recent judicial interpretation of the statute. The Federal Judiciary Act of 1789 included the

${ }^{81} I d$. at $* 3$. The plaintiffs asked the court to consider similar proceedings initiated in Nigeria, which were twice delayed "for personal reasons" of sitting judges, as evidence of the Nigerian forum's inadequacy. Id. at *5 (citing reasons given by Justice Haroun Adamu for dismissal of the Nigerian case, Decl. of Adetunji Oyeypido, Atty. For Defendant Pfizer, Inc., Ex. A at 170).

${ }^{82}$ Id. at *11-13 (finding that the Nuremberg Code and Declaration of Helsinki were nonbinding and that the ICCPR "was not self-executing"). The court also reiterated the earlier court's determination that the case failed to meet a forum non conveniens challenge; thus, forum non conveniens remained a separate ground upon which to dismiss the suit. $I d$. at $* 18$. The court qualified this finding, however, by declaring that the defendant would waive any objection to reappearing in U.S. courts if the plaintiffs filed their complaint in the alternative forum within sixty days, and if the alternative forum then declined jurisdiction. Id.

${ }^{83} 542$ U.S. 692 (2004).

${ }^{84}$ Trovan Case, 2005 WL 1870811, at *10-11.

${ }^{85}$ See infra Part II.B (discussing the Sosa standard). 
ATS, which provides that " $[t]$ he district courts shall have original jurisdiction of any civil action by an alien for a tort only, committed in violation of the law of nations or a treaty of the United States." ${ }^{86}$ The judiciary has witnessed a rapid increase in claims brought under the ATS in the past twenty years. ${ }^{87}$ In interpreting the validity of claims under the ATS, courts have addressed several concerns regarding the statute's applicability to evolving international norms.

The primary debate in ATS litigation involves whether the statute is purely jurisdictional or, alternatively, confers both jurisdiction and a cause of action for alleged violations of international law. This debate emerged with conflicting interpretations of the statute in Filartiga $v$. Pena-Irala ${ }^{88}$ and Tel-Oren v. Libyan Arab Republic ${ }^{89}$ and lacked a definitive resolution until the Supreme Court decided Sosa in 2004. After Sosa, the scope of the ATS narrowed greatly, but the Court has not foreclosed the possibility of the statute's application to new causes of action in limited circumstances. ${ }^{90}$ To the contrary, this Comment argues that despite this narrowing, lack of informed consent is, on its merits, an actionable violation. It concludes that customary international law so strongly establishes informed consent as a prerequisite to involvement in human subjects research that the ATS, even with the Sosa limitations, remains a viable avenue for recovery when research proceeds without valid consent. ${ }^{91}$

${ }^{86} 28$ U.S.C. $\$ 1350(2000)$.

${ }^{87}$ See Lorelle Londis, The Corporate Face of the Alien Tort Claims Act: How an Old Statute Mandates a New Understanding of Global Interdependence, 57 ME. L. REV. 141, 150 (2005) (stating that only twenty-one cases invoked the statute in the first 190 years of its existence, while about eighty cases have attempted to apply it in the past twenty-four years).

${ }^{88} 630$ F.2d 876 (2d Cir. 1980).

89726 F.2d 774 (D.C. Cir. 1984).

${ }^{90}$ See Sosa, 542 U.S. 692, 729 (2004) ("[C] onsiderations persuade us that the judicial power should be exercised on the understanding that the door is still ajar subject to vigilant doorkeeping, and thus open to a narrow class of international norms today.”). The Court declined to apply Erie Railroad Co. v. Tompkins, 304 U.S. 64 (1938), as a substantive bar to any development of federal common law. Id. Beyond meeting the jurisdictional requirements under Sosa, however, individuals who attempt to invoke the ATS must still overcome several other barriers to successful recovery. See infra Part III.D. Importantly, none of these barriers would exclude a court from granting jurisdiction in the class of cases that meet the Sosa standard, while failure to demonstrate an actionable claim under the ATS would.

${ }^{91}$ This Comment focuses on Sosa's definition of customary international law, using the standard set forth in that case to evaluate the legitimacy of the argument that informed consent is part of the customary international law for the purposes of a claim under the ATS. Notably, however, informed consent also meets other criteria for in- 
After Sosa, the question that must be answered by the courts is precisely whether norms governing human subjects protections, and specifically the norms governing informed consent, rise to the level of significance of those torts recognized under the ATS. A greater understanding of ATS jurisprudence facilitates this analysis.

\section{Historical Perspective on the ATS}

When the ATS was enacted as part of the Judiciary Act of 1789, the law of nations comprised two domains. The first domain regarded norms governing interactions among nation-states, ${ }^{92}$ understood to lie within the power of the executive and legislative spheres. ${ }^{93}$ The second domain, located within the judicial sphere, consisted in "a body of judge-made law regulating the conduct of individuals situated outside domestic boundaries and consequently carrying an international savor." ${ }^{94}$ In the two hundred years since the enactment of the ATS,

terpreting what constitutes international law. One widely recognized standard for defining customary international law requires a demonstration of state practice stemming from a perceived legal obligation. See Statute of the International Court of Justice, art. 38(1) (b) (June 26, 1945) (noting that customary international law follows required state practice that stems from legal obligation). Substantial evidence exists to suggest that states perceive a legal obligation to require consent in any experimentation on human persons. See infra Part III.A (chronicling this requirement in numerous legally binding instruments). A second standard for judging the international law examines the degree to which the international community abhors a certain conduct. Under this analysis, the international community considers abstention from the most abhorrent conduct as a peremptory norm. See Donald Francis Donovan \& Anthea Roberts, The Emerging Recognition of Universal Civil Jurisdiction, 100 AM. J. INT'L L.142, 145 (2006) (describing a trend toward recognizing peremptory norms in the international law as applicable to all states and individuals because of the heinous conduct they proscribe). Given the universal animus toward nonconsensual research following the exploitation of human subjects during World War II, see infra Part III.A.1, the element of informed consent would also be considered a peremptory norm in the international context, and as such, it would be actionable conduct in any forum concerned with creating accountability for violations of international law. There is an extensive literature describing both reliance on state practice and the concept of peremptory norms in defining international law. While it is important to note their existence, this Comment will not devote any further attention to either approach, because Sosa's holding controls any decision in a U.S. court considering a potential ATS claim.

${ }^{92}$ See Sosa, 542 U.S. at 714 (stating that this first element included "the science which teaches the rights subsisting between nations or states, and the obligations correspondent to those rights") quoting EMMERICH DE VATTEL, THE LAW OF NATIONS, Preliminaries § 3 (Joseph Chitty \& Edward D. Ingraham eds. and trans., T. \& J.W. Johnson \& Co., 1883), available at http:/ /www.constitution.org/vattel/vattel.htm)).

${ }^{93} I d$.

${ }^{94} I d$. at 715 . 
courts have worked to understand and refine the scope of judge-made law actionable under its provisions. ${ }^{95}$

Section 9 of the Judiciary Act created the ATS to remedy Congress's frustration with its inability to enforce or punish violations of international treaties or of the law of nations. ${ }^{96}$ At its instantiation, the ATS was intended to provide jurisdiction in United States courts for three specific types of offenses in violation of the law of nations: "violations of safe conducts, infringements of the rights of ambassadors, and piracy." ${ }^{\prime 97}$ The ATS sought to address these particular violations because they were commonly considered to require a "judicial remedy and at the same time threaten[ed] serious consequences in international affairs." ${ }^{98}$ Still, even the Sosa Court admitted that, "despite considerable scholarly attention, it is fair to say that a consensus understanding of what Congress intended has proven elusive." ${ }^{99}$

The primary tension the Court considered in Sosa was whether the ATS provides only a jurisdictional basis for a suit in a United States federal court where a cause of action independently exists in international law, or whether the statute also permits the courts to recognize a new cause of action for violations of international law. ${ }^{100}$ These diverging views have resulted, at least in part, from conflicting interpretations of the statute in two landmark cases in ATS jurisprudence: Filartiga v. Pena-Irala ${ }^{101}$ and Tel-Oren v. Libyan Arab Republic. ${ }^{102}$ The Fi-

${ }^{95}$ See supra note 90 and accompanying text (recognizing that the scope of the ATS remains incompletely defined).

${ }^{96}$ See Sosa, 542 U.S. at 716 (determining that Congress wished to "“cause infractions of treaties, or of the law of nations [,] to be punished'" (quoting JAMES MADISON, JOURNAL OF THE CONSTITUTIONAL CONVENTION 60 (E. H. Scott ed., 1893))).

${ }^{97}$ Id. at 715 (citing William BLACKSTONE, 4 COMMENTARIES *68, which identified these three kinds of violations as the "principal offences against the law of nations"). This section discusses the Sosa Court's interpretation of the limitation of jurisdiction to these torts. It is important to note, however, that one possibility for the restriction of recognized torts to these circumstances is that these acts comprised the great majority of interactions in the international context at the time of the statute's creation. In applying the "definable, universal, and obligatory" standard, developed in Sosa to informed consent, see infra Part III.B-C, the growing number of modern international transactions must be considered. This context informs an understanding of those modern torts which reach the level of specificity and concern as those when the statute was enacted must include this as a consideration.

${ }^{98}$ Sosa, 542 U.S. at 715.

${ }^{99} I d$. at 718-19.

${ }^{100}$ See id. at 713 ("The parties and amici here advance radically different historical interpretations of this terse provision.").

${ }^{101} 630$ F.2d 876 (2d Cir. 1980).

102726 F.2d 774 (D.C. Cir. 1984). 
lartiga court took the position that the ATS permits courts to consider new causes of action for violations of international law; the Tel-Oren court rejected that position. ${ }^{103}$ Review of the Sosa Court's consideration of both cases favors the Filartiga approach by recognizing violations of international norms as part of the federal common law. The Court, however, advised caution in exercising judicial power to create new causes of action under the federal common law.

\section{Filartiga and Tel-Oren}

In 1980, Filartiga, which involved violations of international norms prohibiting torture, broadly expanded the reach of the ATS. As one scholar has summarized: ${ }^{104}$

The Second Circuit found that: (1) the law of nations is part of the federal common law, such that cases arising under it arise under the laws of the United States as required by Article III of the Constitution; (2) the law of nations "'may be ascertained by consulting the works of jurists, writing professedly on public law; or by the general usage and practice of nations; or by judicial decisions recognizing and enforcing that law'"; ${ }^{105}$ (3) a norm must "command 'the general assent of civilized nations,", 106 to be part of the law of nations; (4) the law of nations must be interpreted "not as it was in 1789 , but as it has evolved and exists among the nations of the world today."

The Second Circuit's findings and reasoning in Filartiga imply that the law of nations is dynamic, and the ATS enjoyed a period of expansive interpretation following the holding in that case. ${ }^{108}$ While the Supreme Court later narrowed the application of the ATS in Sosa, it expressly stated that the ATS is not limited only to the narrow set of offenses initially granted jurisdiction by courts under the common law

103 See infra Part II.B.2 (discussing the Filartiga and Tel-Oren decisions).

${ }^{104}$ Pauline Abadie, A New Story of David and Goliath: The Alien Tort Claims Act Gives Victims of Environmental Injustice in the Developing World a Viable Claim Against Multinational Corporations, 34 GOLDEN GATE U. L. REV. 745, 758 (2004).

${ }^{105}$ Id. (quoting Filartiga, 630 F.2d at 880 (quoting United States v. Smith, 18 U.S. (5 Wheat) 153, 160-61 (1820))).

${ }^{106}$ Id. (quoting Filartiga, 630 F.2d at 881 (quoting The Paquete Habana, 175 U.S. $677,694(1900)))$.

${ }^{107}$ Id. (quoting Filartiga, 630 F.2d at 881 (original footnotes omitted)).

${ }^{108} I d$. at 757 ("Before 1980, the [ATS's] jurisprudence only consisted of two cases. The Second Circuit's ruling in Filartiga v. Pena-Irala gave the [ATS] a new unexpected dimension." (footnote omitted)). 
at the time of its enactment. ${ }^{109}$ The Sosa Court recognized the dynamic nature of the law of nations, and the Court continues to accept that appropriate interpretation of the law of nations can evolve through the creation of federal common law. However, the Court also clarified that the law of nations would include only binding international treaties or customary international law that matched the degree of international concern for the three actionable violations initially recognized under ATS jurisdiction. ${ }^{110}$ While ultimately respecting the Filartiga position on the dynamic nature of the ATS, the Sosa Court also addressed challenges to the Filartiga approach voiced in Tel-Oren.

In large part, the Sosa decision was influenced by the divided court that wrote a plurality opinion in Tel-Oren. ${ }^{111}$ The Tel-Oren court considered the applicability of the ATS to an attack on a civilian bus in Israel. The bus was seized by members of the Palestine Liberation Organization, and the plaintiffs, mostly Israeli citizens who were or who represented victims of the attack, named as defendants the Libyan Arab Republic and various Arab organizations. ${ }^{112}$ In deciding the merits of the case, the issue of jurisdictional versus substantive authority of the ATS sharply fractured the court. In a concurring opinion, Judge Edwards supported the view of the Filartiga court and found a cause of action under the ATS, which "required only a showing that the defendant's actions violated the substantive law of nations." Judge Bork, also filing a concurrence, favored a more restrictive view of the ATS, writing that, "it is essential that [the allegedly violated law create] an explicit grant of a cause of action before a private plaintiff be allowed to enforce principles of international law in a federal tribunal." 114 The disagreement between Edwards and Bork in the TelOren case renewed the debate following Filartiga and its progeny over

${ }^{109}$ Sosa v. Alvarez-Machain, 542 U.S. 692, 715, 724 (2004) (listing "violation of safe conducts, infringement on the rights of ambassadors, and piracy" as the three principal causes of action initially given practical effect by the ATS).

${ }^{110}$ See infra Part II.B.3 (discussing the Sosa standard).

${ }^{111}$ See Sosa, 542 U.S. at 731 ("[F] or practical purposes the point of today's disagreement has been focused since the exchange between Judge Edwards and Judge Bork in Tel-Oren v. Libyan Arab Republic ....").

${ }^{112}$ See Tel-Oren v. Libyan Arab Republic, 726 F.2d 774, 775 (D.C. Cir. 1984).

${ }^{113}$ Id. at 777 (Edwards, J., concurring).

${ }^{114}$ Id. at 801 (Bork, J., concurring). Bork expressly rejected Edwards's approach to ATS applicability, believing it to be "fundamentally wrong." Id. 
the scope of the ATS. ${ }^{115}$ The Supreme Court settled this debate when it decided Sosa in 2004.

\section{The Sosa Standard Defined: A Jurisdictional Statute Recognizing Federal Common Law}

In attempting to navigate the divergent approaches to jurisdiction and merits in the Filartiga and Tel-Oren cases, the Sosa Court opted for middle ground. When it established the standard for applicability of the ATS to potential new causes of action, the Sosa Court clearly stated that the statute was intended to be jurisdictional in nature. ${ }^{116}$ Some read this finding to support the position that the only actionable claims under the ATS are those which are self-executing, that is, those which allege a violation of an international norm that itself grants a private right of action. The Sosa Court in fact held that the International Covenant on Civil and Political Rights (ICCPR) was not a sufficient source for implicating the ATS as a remedy because the ICCPR was not intended to be self-executing. ${ }^{117}$ Closely read, however, Sosa states that the ICCPR itself cannot be the sole source of international law relied upon to support an ATS action. ${ }^{118}$ Nonetheless, the Court also held that Congress passed the ATS with the intent that it would have an immediate practical effect, conferring a cause of action on the merits for the three violations that were considered to be part of the federal common law at the time. ${ }^{119}$ To give effect to both conclusions, the Court provided that, under certain circumstances, the judiciary has the authority to develop the federal common law beyond those violations actionable at the enactment of the ATS. ${ }^{120}$ In exercising this authority, the judiciary should be guided by the same consid-

${ }^{115}$ See Kontorovich, supra note 12, at 115-18 (describing the cases and controversy following Filartiga).

${ }^{116}$ Sosa, 542 U.S. at 713-14 (citing, among other reasons, the placement of the ATS in section 9 of the Judiciary Act of 1789, which was concerned with federal jurisdiction, as proof of congressional intent that the statute be considered in terms of its jurisdictional authority).

${ }^{117}$ Id. at 728 .

${ }^{118} I d$. at $728-31$.

${ }^{119} I d$. at 719-20 (arguing that two proposed interpretations of the ATS supported application to a limited set of offenses that were at the time considered violations of the law of nations).

${ }^{120} I d$. at 724 ("The jurisdictional grant is best read as having been enacted on the understanding that the common law would provide a cause of action for the modest number of international law violations with a potential for personal liability at the time."). 
erations that motivated the recognition of the initial violations under the ATS. ${ }^{121}$ Further describing this standard, the Court explained:

Whatever the ultimate criteria for accepting a cause of action subject to jurisdiction under [the ATS], we are persuaded that federal courts should not recognize private claims under federal common law for violations of any international law norm with less definite content and acceptance among civilized nations than the historical paradigms familiar when [the ATS] was enacted .... This limit upon judicial recognition is generally consistent with the reasoning of many of the courts and judges who faced the issue before it reached this Court. ${ }^{122}$

Among the prior courts that had considered this issue, the Sosa Court expressly noted the Filartiga approach. ${ }^{123}$ While the Sosa Court added restrictions to Filartiga's holding, the Court nevertheless accepted it.

\section{INFORMED CONSENT MEETS THE SOSA STANDARD FOR A NORM OF CUSTOMARY INTERNATIONAL LAW}

When Filartiga resurrected the ATS in 1980, it became the first modern case in ATS jurisprudence to express the United States's views on the statute's applicability and reach. Filartiga established that the ATS would apply to certain violations of human rights. To determine which human rights were qualified to become part of the federal common law, the court relied on its understanding of customary international law:

[W] here there is no treaty, and no controlling executive or legislative act or judicial decision, resort must be had to the customs and usages of civilized nations; and, as evidence of these, to the works of jurists and commentators, who by years of labor, research and experience, have made themselves peculiarly well acquainted with the subjects of which they treat. Such works are resorted to by judicial tribunals, not for the speculations of their authors concerning what the law ought to be, but for trustworthy evidence of what the law really is. ${ }^{124}$

Essentially, the Court has looked to scholars and jurists to develop a standard for customary law that includes those violations of norms that are "definable, universal and obligatory." ${ }^{125}$ The facts in Sosa ${ }^{126}$

121 Id.

${ }^{122}$ Id. at 732 .

123 Id.

${ }^{124}$ Id. at 734 (quoting The Paquete Habana, 175 U.S. at 700 (quotation marks omitted)).

${ }^{125}$ Id. at 732 (quoting Tel-Oren v. Libyan Arab Republic, 726 F.2d 774, 781 (D.C. Cir. 1984) (Edwards, J., concurring)); see also Abadie, supra note 104, at 763-68 (de- 
did not meet this standard, because "a single illegal detention of less than a day, followed by the transfer of custody to lawful authorities and a prompt arraignment, violates no norm of customary international law so well defined as to support the creation of a federal remedy." ${ }^{127}$ Additionally, the Court stated that creating a private cause of action in this specific case-a short-term arbitrary arrest and detention-would go beyond any common law recognition of such a norm. ${ }^{128}$ In drawing this conclusion, the Court implied that a more defined norm, ${ }^{129}$ and one that was widely actionable in common law, would provide stronger support for creating a private right of action under the federal common law. ${ }^{130}$ Importantly, the Court noted that the "definable, universal and obligatory standard" does not demand that the international norm actually be declared universally; instead, the standard means that the violation of the norm must be universally condemned and that the norm must be specific. Applying that interpretation in the context of human subjects protections, it follows that the wide condemnation of research without voluntary consent, com-

scribing four standards by which courts could interpret customary international law, and noting that the most common is the "definable, universal and obligatory standard"). Abadie criticizes the judiciary's narrow approach to customary international law, advocating a broader reading based on the Restatement (Third) of Foreign Relations Law, in which a norm need not be universal to be considered customary international law. See Restatement (THIRD) OF FOREIGN RELATIONS LAW § 102(1)-(3) (1987) (allowing "widely accepted" rules or agreements to satisfy the requirements for customary international law).

${ }^{126}$ United States authorities suspected that the defendant in Sosa, Humberto Alvarez-Machain (Alvarez), was involved in the torture of a Drug Enforcement Administration (DEA) officer in connection with the officer's assignment in Mexico. Sosa, 542 U.S. at 697 . The DEA requested the Mexican government's assistance in bringing Alvarez to the United States. Id. at 698 . When the Mexican government could not assist, the DEA "approved a plan to hire Mexican nationals [including petitioner Sosa] to seize Alvarez and bring him to the [U.S.] for trial." Id. While carrying out this plan, the petitioners "abducted" Alvarez from his home and held him in a motel for one night prior to flying him to the United States, at which point he was "arrested by federal officers." Id.

${ }^{127}$ Id. at 738 .

${ }^{128} I d$. (stating that creating a private cause of action for this violation would exceed the Court's discretion).

${ }^{129}$ Alvarez-Machain cited only two sources of international law, neither of which indicated that an arrest of the length he endured would be considered a violation of binding international law. See id. at 734 (discussing Alvarez-Machain's claims under the UDHR and ICCPR).

${ }^{130} I d$. at 712 ("Although we agree the statute is in terms only jurisdictional, we think at the time of enactment the jurisdiction enabled federal courts to hear claims in a very limited category defined by the law of nations and recognized at common law."). 
bined with the consistency in the definition of what informed consent specifically requires, does meet the standard described in Sosa.

\section{A. Human Subjects Protections Require Informed Consent}

Several bodies-including the Nuremberg International Military Tribunal, the World Medical Association, the United Nations, the Council for International Organizations of Medical Sciences, and the International Conference on Harmonisation-have promulgated international guidelines governing research using human subjects. Together, these entities establish varied degrees of protection for human subjects, and even more varied degrees of enforcement. ${ }^{131}$ Moreover, the multiple policies carry different legal weight in the international context. ${ }^{132}$ Consistent among them, however, is the imperative that informed consent be secured from each subject prior to participating in medical experimentation.

To understand how informed consent meets the Sosa standard, an examination of the international instruments governing informed consent is necessary.

\section{Nuremberg Code}

Following World War II, the Nuremberg Trials resulted in a statement of the first international standards attributable to human subjects research. ${ }^{133}$ The statement, which came to be called the "Nuremberg Code," comprises the principles set forth by the post-war military tribunals in United States $v$. Brandt. ${ }^{134}$ The Code reflects the

${ }^{131}$ While the provisions of these instruments differ significantly, areas of overlap should create a strong persuasive force for defining customary international law.

${ }^{132}$ When considering application of the ATS to clinical research abroad, the legal force of the various policies becomes salient. See supra notes 96-99 and accompanying text (discussing the "law of nations" designation as a requirement for a valid ATS claim)

${ }^{133}$ See Meier, supra note 40, at 523 (“[T] he Nuremberg Code became the first international standard defining permissible medical experiments.").

${ }^{134}$ See 2 Trials of WAR Criminals Before the Nuernberg Tribunals Under CONTROl Council LaW No. 10, at 189, 237 (U.S. Gov't Printing Office, 1946-1949) [hereinafter NUREMBERG CODE]. The Nuremberg Tribunals examined numerous allegations of war crimes. The Doctors' Trial or Medical Case, two names by which the Brandt trial was also known, involved all of the doctors allegedly responsible for conducting cruel medical experiments on unsuspecting subjects during World War II. See infra note 135 (describing these medical experiments). The principles now called the Nuremberg Code were included in the decision of the Brandt court, see NuREMBERG 
thoughts of the tribunal judges in Brandt after they examined the atrocities committed in the name of medical experimentation during the War. ${ }^{135}$ The purpose of the Nuremberg Code was to obligate investigators never to repeat these behaviors. The Nuremberg Code became an official part of the record of the Nuremberg International Military Tribunal, composed of a body of representatives from the United States, the French Republic, Great Britain and Northern Ireland, and the Soviet Union. ${ }^{136}$

The Nuremberg Code established ten principles for medical experimentation using human subjects. ${ }^{137}$ The most fundamental aspect of the Code is its provision on informed consent:

The voluntary consent of the human subject is absolutely essential.

This means that the person involved should have legal capacity to give consent; should be so situated as to be able to exercise free power of choice, without the intervention of any element of force, fraud, deceit, duress, over-reaching, or other ulterior form of constraint or coercion; and should have sufficient knowledge and comprehension of the elements of the subject matter involved as to enable him to make an understanding and enlightened decision. ${ }^{138}$

CODE, supra. at 181-82, and are reprinted at http://ohsr.od.nih.gov/guidelines/ nuremberg.html.

${ }^{135}$ Involuntary medical experimentation was prevalent during World War II:

[E]xperiments included freezing experiments (subjects were forced to remain in a tank of ice water for periods up to 3 hours), malaria experiments (subjects were deliberately infected with malaria to investigate immunization procedures), sulfanilamide experiments (subjects were deliberately wounded and then infected with bacteria such as streptococcus, gas gangrene, and tetanus), typhus experiments (subjects were deliberately infected with spotted fever virus merely to keep the virus alive), and poison experiments (subjects were deliberately shot with poisoned bullets and then killed immediately to permit autopsies). The subjects ... neither benefited from such treatments nor gave voluntary consent to them.

Meier, supra note 40, at 521-22 (footnote omitted).

${ }^{136}$ See Agreement for the Prosecution and Punishment of Major War Criminals of the European Axis and Charter of the International Military Tribunal Preamble, Aug. 8, 1945, 82 U.N.T.S. 280, available at http://www.icrc.org/ihl.nsf/FULL/350?OpenDocument (listing the parties to the agreement).

${ }^{137}$ NUREMBERG CODE, supra note 134, at 181-82.

${ }^{138} I d$. at 181 (emphasis added). The Code further states that, "[d]uring the course of the experiment the human subject should be at liberty to bring the experiment to an end if he has reached the physical or mental state where continuation of the experiment seems to him to be impossible." Id. at 182 . Permitting a subject to terminate her participation at will reinforces the belief that research should be conducted only on voluntary and willing subjects. The Nuremberg Code also contains provisions relating to the utility of the experiment, and requirements for preexisting animal studies, avoidance of physical and mental suffering, adequacy of facilities and 
The Nuremberg Code thus describes a customary understanding of the need for consent when conducting research in a global setting and provides the definitive elements of valid consent. ${ }^{139}$

\section{Declaration of Helsinki}

The World Medical Association, a global organizing body for physicians, adopted the Declaration of Helsinki in 1964 to generate a selfregulating mechanism to protect human subjects internationally. ${ }^{140}$ Like the Nuremberg Code, the Declaration of Helsinki contains provisions requiring the consent of subjects prior to their participation in research:

In any research on human beings, each potential subject must be adequately informed of ... the anticipated benefits and potential risks of the $[$ research $] ..$. The subject should be informed of the right to abstain from participation in the study or to withdraw consent to participate at any time without reprisal. ... [T] he physician should then obtain the subject's freely-given informed consent, preferably in writing.

... [T] he physician should be particularly cautious if the subject is in a dependent relationship with the physician or may consent under duress.

qualified staff, and procedures for termination if a study is found to create excessive risks to participants. Id. The Code additionally calls for abstention when there is a belief that death or severe disability is possible, or when risk to the individual is disproportionate to the expected benefit to the larger community. Id.

${ }^{139}$ But see Meier, supra note 40, at 523 (conceding that the Nuremberg Code is "not a binding international treaty").

${ }^{140}$ WORLD MED. ASS'N, WORLD MEdiCAL ASSOCIATION DECLARATION OF HELSINKI: Ethical PRinciples fOR RESEARCH INVOlving Human Subjects (2004), available at http://www.wma.net/e/policy/pdf/17c.pdf [hereinafter HELSINKI VI]. Following its development in 1964, the Declaration has been amended five times. For example, in 1975, the document included provisions for ethics committee review of research; in 1996, the WMA added provisions regarding the use of placebos. See Delon Human \& Sev S. Fluss, The World Medical Association's Declaration of Helsinki: Historical and Contemporary Perspectives 6 (July 25, 2001) (unpublished paper, draft on file with the World Medical Association), available at http://www.wma.net/e/ethicsunit/pdf/ draft_historical_contemporary_perspectives.pdf. The 2000 amendments made significant changes, including controversial changes regarding research done in the course of medical care. Id. at 17. Despite the controversy, scholars agreed that the 2000 revisions were designed to maintain this document as "the cornerstone of biomedical research [as it has been] for the last 30 years and the largely unquestioned anchor for ethical decision-making in clinical trials." $I d$. at 2 (quotation marks and brackets omitted). Although the WMA added a clarification to paragraph 30 in 2004, the 2000 version contains the last substantial revision of the document.

${ }^{141}$ HELSINKI VI, supra note 140, $§$ 22-23. 
The Declaration of Helsinki is widely accepted as the most influential guidance document in the creation of statutory protections for human subjects. ${ }^{142}$ "The Declaration of Helsinki . . is the fundamental document in the field of ethics in biomedical research and has influenced the formulation of international, regional and national legislation and codes of conduct." ${ }^{143}$ Fifteen countries-Australia, Belgium, Brazil, China, Germany, India, Israel, Japan, New Zealand, Norway, South Africa, Switzerland, Uganda, the United Kingdom, and the United States-adhere to the principles set forth in the Declaration of Helsinki regarding the conduct of acceptable clinical trials involving human subjects. ${ }^{144}$ While some countries require even

${ }^{142}$ See COUNCIL FOR INT'L ORgS. OF MED. Scis. (CIOMS), INTERNATIONAL ETHICAL Guidelines FOR Biomedical RESEARCH InVOlVing Human Subjects, "International Instruments and Guidelines" (2002), available at http://www.cioms.ch/ guidelines_nov_2002_blurb.htm [hereinafter CIOMS GUIDELINES] (providing guidelines for the implementation of the Declaration of Helsinki); INT'L CONFERENCE ON Harmonisation: GoOd Clinical PRACTICE: CONSOlidated Guideline $\S 2.1, r e-$ printed in 62 Fed. Reg. 25,691, 25,695 (May 9, 1997) [hereinafter ICH GuIDELINES] ("Clinical trials should be conducted in accordance with the ethical principles that have their origin in the Declaration of Helsinki ....”). But see Meier, supra note 40, at 526 (criticizing the Declaration of Helsinki as less protective than the Nuremberg Code). Meier comments on the distinction between therapeutic versus nontherapeutic research, which was created in the original 1965 formulation of the Declaration of Helsinki and preserved in the modern version. This distinction established separate considerations when research was performed for partially therapeutic rather than solely investigative purposes. See HELSINKI VI, supra note 140, §§ 28-32 (enumerating additional considerations when medical research is combined with medical care); $c f$. WORLD MEd. ASS'N, WORLd MEDICAL ASSOCIATION DECLARATION OF HELSINKI: ETHICAL PRINCIPLES FOR RESEARCH INVOLVING HUMAN SUBJECTS, pts. II-III (1996), available at http://www.cirp.org/library/ethics/helsinki/ (providing the original formulation of the Declaration of Helsinki). When examined carefully, the earlier version shows a more explicit description of a distinction between "clinical" (or therapeutic) research and "non-clinical biomedical" (or nontherapeutic) research. Additionally, it provided that a physician could suspend the requirement of consent when research was therapeutic, if the physician declared her reasons for doing so. See id. § II.5. In the 2000 version of the Declaration of Helsinki, this provision no longer appears; it remains absent from the current (2004) version. The change may represent recognition of the possibility for exploitation under the therapeutic misconception. See supra note 65 and accompanying text (defining the therapeutic misconception and discussing its relation to the exploitation of human research subjects).

${ }^{143}$ CIOMS GUIDELINES, supra note 142.

${ }^{144}$ See Human \& Fluss, supra note 140, at 8-11 (citing statements or laws from all fifteen of these countries, each adhering to principles put forth in the Declaration of Helsinki regarding the conduct of acceptable clinical trials within their borders); see also Nat'l Health \& Med. Research Council, National Statement on Ethical CONDUCT IN RESEARCH INVOLVING Humans 2 (1999) (citing the trend for nations to publish research ethics codes that observe the standards of the Declaration of Helsinki, and noting that Australia "has followed these trends" in documents such as the Austra- 
stronger protections than Helsinki mandates, this fact does not undermine the characterization of Helsinki as a universal minimum standard for ethics in research. ${ }^{145}$

lian Statement on Human Experimentation); Marie-Luce Delfosse, Research Committees and the Principle of Justice: Putting Ethics and Law to the Test, in ReSEARCH ON Human SubJECTS: ETHICS, LAW, AND SOCIAL POLICY 286, 286-300 (David N. Weisstub ed., 1998) (discussing Belgian legislation); NAT'L Drug REgulation AdMIN., Drug Clinical TRIAL AdMINISTRATION NORMS (Sept. 1, 1999) (referencing, in English translation, Brazilian norms); Human \& Fluss, supra note 140, at 8 \& nn.43-44 (citing official Chinese regulations requiring compliance with Helsinki principles for all research involving human subjects); INDIAN COUNCIL OF MED. RESEARCH, ETHICAL GUIDELINES FOR BIOMEDICAL RESEARCH ON HuMAN SubJECTS 7 (2000) (referencing Indian national legislation drawn from international codes, including the Declaration of Helsinki); Health Research COUNCIL OF N.Z., Guidelines on ETHiCS IN HEAlth Research (2002) (describing New Zealand's guidelines); NORWEgIAN Ministry OF EDUC. \& RESEARCH, TERMS OF REFERENCE FOR THE REgIONAL COMMITTEES FOR MEDICAL RESEARCH ETHICS (last amended July 1, 2003) (on file with the author) (prescribing conformity to the Declaration of Helsinki); SWISS FED. COUNCIL, ORDINANCE ON CLINICAL Trials of Therapeutic Products, GoOd Practices for Clinical Trials $\S 1$, art. 4 (Dec. 15, 2000) (incorporating the Declaration of Helsinki's principles through the ICH Guidelines); SOUTH AFriCAN MED. COUNCIL, GuIDELINES ON ETHICS FOR MEDICAL RESEARCH $\$ \$ 1,4.7$ (1993) (indicating agreement with the principles in the Declaration of Helsinki); ROYAL COLL. OF PHYSICIANS OF LONDON, GUIDELINES ON THE Practice of EThics CommitTeEs in Medical RESEARCH INVOlving Human Subjects 3 (3d ed. 1996) (adding the United Kingdom's incorporation of Helsinki principles).

${ }^{145}$ The example of Switzerland demonstrates this point. In the early 1990s, Swiss regulations referred to the Declaration of Helsinki as "the ethical basis of clinical trials," and required that the Declaration "be fully known to, and complied with by, any person involved in a research activity on man." Human \& Fluss, supra note 140, at 9-10 (describing an informal translation of the 1993 Swiss Regulations on medicines at the clinical trial stage). Though the current Swiss guidelines require compliance with ICH Guidelines, see supra note 144, the Swiss government's shift to more direct reliance on ICH principles does not undermine the value or authority of the Declaration of Helsinki with regard to informed consent. Instead, the shift can be seen as a trend toward providing even greater protection for human subjects by recognizing what are considered stronger ethical guidelines governing research. See supra note 39 (discussing the view that the ICH guidelines are thought to provide stronger protection than the Declaration of Helsinki). Some commentators, such as Lurie and Greco, have criticized this trend, characterizing it as a deviation from the Declaration's fundamental principles governing research. See supra note 55. Instead, new guidelines may attempt "to indicate how the fundamental ethical principles ... as set forth in the Declaration of Helsinki, could be applied effectively, particularly in developing countries, taking into account culture, socioeconomic circumstances, national laws, and executive and administrative arrangements." Human \& Fluss, supra note 140, at 7 (noting this objective in the CIOMS guidelines (citation and quotation marks omitted)); see also infra notes 146-51 and accompanying text (discussing the CIOMS guidelines). Importantly, across these documents, the definition and elements of informed consent remain consistent. The pervasive belief that the principles in the Declaration of Helsinki must be followed wherever research occurs mandates support for the Declaration's notion of consent, which is reiterated throughout the subsequent documents that are meant to expand upon it. While the individual documents may differ in other regards, the principle of 


\section{CIOMS International Ethical Guidelines for Research Involving Human Subjects}

The Council for International Organizations of Medical Sciences (CIOMS) is an international nongovernmental organization, established in 1949, which operates under specific relations with the United Nations (UN) and two UN agencies, the World Health Organization (WHO) ${ }^{146}$ and the United Nations Educational, Scientific and Cultural Organization (UNESCO). ${ }^{147}$ In the 1970s, the CIOMS began its work on ethics in biomedical research, with the purpose of creating guidelines "to indicate how the ethical principles that should guide the conduct of biomedical research involving human subjects, as set forth in the Declaration of Helsinki, could be effectively applied, particularly in developing countries, given their socioeconomic circumstances, laws and regulations, and executive and administrative arrangements." 148

The report creates three ethical principles for conducting biomedical research-respect for persons, beneficence, and justice-and formulates guidelines to realize these goals. ${ }^{149}$ Embedded within the principle of "respect for persons" is respect for the notion of autonomy and each individual's right to and capacity for selfdetermination. ${ }^{150}$ An individual must be given an opportunity to deliberate over personal choices in order to respect her right to selfdetermination; the researcher achieves this by following the guidelines applicable to informed consent. ${ }^{151}$ Thus, informed consent is crucial to the CIOMS principles guiding biomedical research.

consent itself meets the standard necessary for recognition of a customary norm of international law. See infra Part III.B. (explaining how informed consent meets the standard for a norm of customary international law).

${ }^{146}$ The World Health Organization also promulgates guidelines for good clinical practices for clinical trials. See CIOMS GuIDELINES, supra note 142, at "International Instruments and Guidelines" (discussing the WHO's issuance of clinical guidelines in 1995).

${ }^{147}$ Id. at "Background."

${ }^{148} I d$.

${ }^{149}$ See id. at "General Ethical Principles" (listing and explaining these three basic principles).

${ }^{150} I d$.

${ }^{151}$ See id. at "Guidelines 4-6" (discussing the need for individual informed consent, the elements of a valid informed consent disclosure, and the obligations of sponsors and investigators in obtaining informed consent). 


\section{International Conference on Harmonisation: Good Clinical Practices}

The International Conference on Harmonisation (ICH) represents an international initiative to bring together regulators and industry representatives to decide the procedures necessary to "ensure and assess the safety, quality and efficacy of medicines." established guidelines for good clinical practices in the conduct of clinical research involving human subjects include specific guidelines relating to informed consent:

[Informed consent is a] process by which a subject voluntarily confirms his or her willingness to participate in a particular trial, after having been informed of all aspects of the trial that are relevant to the subject's decision to participate. Informed consent is documented by means of a written, signed, and dated informed consent form. ${ }^{153}$

To ensure valid informed consent, investigators must comply with the detailed regulatory guidelines set forth by the ICH. ${ }^{154}$

\section{United Nations Provisions}

Two major human rights instruments created by the United Nations are also relevant to the conduct of clinical trials in developing countries: the Universal Declaration on Human Rights (UDHR) and the International Covenant on Civil and Political Rights (ICCPR). The UDHR establishes that " $[\mathrm{n}]$ o one shall be subjected to torture or to cruel, inhuman or degrading treatment or punishment." ${ }^{155}$ Arguably, in the historical context of the signing of the UDHR, just following World War II and the express condemnation of nonvoluntary human experimentation in the Nuremberg Trials, the UDHR alone stands to support a requirement for informed consent in human subjects research. Nonetheless, the document has been criticized for its

${ }^{152}$ See International Conference on Harmonisation (ICH), Structure of ICH, http:/ /www.ich.org (follow "Structure of ICH" hyperlink) (last visited Oct. 22, 2006). Members of the ICH include regulatory and industry representatives from the United States, the European Union, and Japan. Id. The guidelines resulting from this initiative therefore represent a consensus among industry and regulatory perspectives regarding the protections that should universally apply to human subjects.

${ }^{153}$ ICH GuIDELINES, supra note 142, § 1.28 (Informed Consent), reprinted in 62 Fed. Reg. at 25,694.

${ }^{154}$ Id. $\S 4.8$ (Informed Consent of Trial Subjects), reprinted in 62 Fed. Reg. at 25,697 .

${ }^{155}$ Universal Declaration of Human Rights art. 5, G.A. Res. 217A, at 73, U.N. GAOR, 3d Sess., 1st plen. mtg., U.N. Doc. A/810 (Dec. 10, 1948) [hereinafter UDHR]. 
lack of specificity. ${ }^{156}$ The UN also has developed numerous international human rights covenants, which carry the legally binding status of treaties. One in particular, the ICCPR, ${ }^{157}$ adds specificity to the obligations under the UDHR. Article 7 of the ICCPR states that " $[n]$ o one shall be subjected to torture or to cruel, inhuman or degrading treatment or punishment. In particular, no one shall be subjected without his free consent to medical or scientific experimentation." ${ }^{158}$ The language of this statement implies that medical or scientific experimentation without free consent is tantamount to "inhuman or degrading treatment." In fact, some people opposed the addition of the second sentence primarily because they felt the first sentence obviously included medical experimentation; it was eventually included because of the perceived weight of the importance of informed consent in the aftermath of the Nuremberg Trials. ${ }^{159}$ While preserving the sentiment of the UDHR, the ICCPR gives force to these guidelines, and United States courts have recognized that the ICCPR has binding status as international law. ${ }^{160}$

\section{Convention on Human Rights and Biomedicine}

The European Convention on Human Rights and Biomedicine (CHRB) is "the first legally binding international treaty to [specifi-

\footnotetext{
${ }^{156}$ See Meier, supra note 40, at 534 (noting that the Declaration "lacks the specificity to provide a link to human experimentation").

${ }^{157}$ International Covenant on Civil and Political Rights (XXI), Annex, G.A. Res. 2200, U.N. Doc. A/6316 (Dec. 16, 1966) [hereinafter ICCPR].

${ }^{158}$ Id. art. 7.

159 See Annotations on the Text of the Draft International Covenants on Human Rights, U.N. GAOR, 10th Sess., Annex, agenda item 28 (Part II) at 31, II 14, U.N. Doc. A/2929 (July 1, 1955) (explaining that the second clause was included to reiterate the importance of informed and free consent in the wake of World War II atrocities). For a more detailed consideration of this view, see David P. Fidler, "Geographical Morality" Revisited: International Relations, International Law, and the Controversy Over PlaceboControlled HIV Clinical Trials in Developing Countries, 42 HARV. INT'L L.J. 299, 328-37, 34244 (2001) (asserting that Article 7 implicates both the provisions against inhuman or degrading treatment and the right to life). But see Part II.B.3 (discussing the Sosa Court's view that the ICCPR alone could not form the basis of an ATS claim).

${ }^{160}$ See Trovan Case, No. 01 CIV 8118, 2005 WL 1870811, at *9, *13 (S.D.N.Y. Aug. 9, 2005) (stating that activities in violation of the law of nations also violate U.S. laws). Nonetheless, this finding was not sufficient for the court to recognize a private right of action or to award relief under the ATS on the basis of the violation. See id. at*13; see also infra Part III.B (discussing elements required for application of the ATS to clinical trials conducted without informed consent).
} 
cally] govern human experimentation." ${ }^{161}$ Article 5 of this agreement delineates the primary requirements for informed consent:

An intervention in the health field may only be carried out after the person concerned has given free and informed consent to it.

This person shall beforehand be given appropriate information as to the purpose and nature of the intervention as well as on its consequences and risks.

The person concerned may freely withdraw consent at any time. ${ }^{162}$

When the intervention contemplated is carried out in the context of scientific research, the agreement further provides in article 16 that " $[\mathrm{r}]$ esearch on a person may only be undertaken if ... the persons undergoing research have been informed of their rights and the safeguards prescribed by law for their protection," and "the necessary consent as provided for under article 5 has been given expressly, specifically and is documented. Such consent may be freely withdrawn at any time." 163 Adopted by the majority of European Union (EU) member states ${ }^{164}$ and currently applicable in nineteen of those, ${ }^{165}$ the CHRB confirms that informed consent is considered mandatory in all cases in which investigators conduct research on human subjects. Like the ICCPR, the CHRB is binding on the states to which it applies. ${ }^{166}$

\section{B. Informed Consent Is Universal, Definable, and Obligatory}

In assessing whether informed consent meets the rigorous standard established by Sosa, courts must decide whether the combined scope of ethical guidelines governing informed consent defines this principle as a customary norm of international law. Sosa states that

${ }^{161}$ Meier, supra note 40 , at 528. The ICCPR is also a legally binding document. See supra note 160 and accompanying text. The ICCPR's primary purpose, however, is to provide a more general discussion of political rights, whereas the CHRB is the first international text to focus on human rights in the medical context.

${ }^{162}$ Council of Europe, Convention on Human Rights and Biomedicine ch. II, art. 5, 36 I.L.M. 817, 821 (1997) [hereinafter CHRB].

${ }^{163}$ Id. at 822; see also Meier, supra note 40, at 528 (citing CHRB articles 5 and 16 to describe that document's rule for informed consent).

${ }^{164}$ Council of Europe Treaties, Convention on Human Rights and Biomedicine http://www.coe.int/t/e/legal_affairs/legal_cooperation/bioethics/texts_and_documents/ 1Treaties_COE.asp (follow "Chart of Signatories and Ratifications" hyperlink) (last visited Oct. 22, 2006) (listing thirty-four of the forty-five EU member states as signatories).

${ }^{165} I d$. (confirming ratification and entry into force in nineteen member states).

${ }^{166}$ See Meier, supra note 40, at 528 (discussing the binding nature of the CHRB and its content regarding free and informed consent). 
such norms must be "definable, universal and obligatory." ${ }^{167}$ Informed consent meets each criterion.

\section{The Mandate for Informed Consent is Universal}

The principle that human subjects research mandates informed consent is universal. Ruth Macklin ${ }^{168}$ writes:

An undisputed criterion for determining that research is, in fact, exploitative is failure to provide the information necessary for properly obtained consent: telling potential subjects that they are being invited to participate in research, lack of an adequate explanation of the risks, potential benefits, procedures to be performed and alternative treatments, and failure to ensure that the potential subjects understand what they have been told and agree voluntarily to participate. ${ }^{169}$

International instruments concerning human subjects research confirm Macklin's conclusion. The ICCPR, for example, represents international condemnation of the practice of medical experimentation without participants' informed consent. ${ }^{170}$ In addition to the ICCPR, FDA regulations also apply the requirement of informed consent to U.S. investigators' conduct of research domestically ${ }^{171}$ and in

${ }^{167}$ Sosa v. Alvarez-Machain, 542 U.S. 692, 732 (2004) (quoting Tel-Oren v. Libyan Arab Republic, 726 F.2d 774, 781 (D.C. Cir. 1984) (Edwards, J., concurring)); see also supra note 125 and accompanying text (elaborating on Sosa's interpretation of this standard).

${ }^{168}$ As the author of a scholarly treatise on the subject of ethical standards for research in developing countries, Macklin qualifies as the precise kind of authority "who by years of labor, research, and experience [has] made [herself] peculiarly well acquainted with the subject which [she] treats." Sosa, 542 U.S. at 734. In its decision, the Sosa Court explicitly stated that, in the absence of a "controlling executive or legislative act or judicial decision," courts rely on the "works of [experienced] jurists and commentators ... not for the speculations of their authors concerning what the law ought to be, but for trustworthy evidence of what the law really is." Id.; see also supra note 124 and accompanying text.

${ }^{169}$ MACKLIN, supra note 19, at 100 (emphasis added). The author goes on to write that, " $[\mathrm{t}] \mathrm{o}$ the extent that these elements were lacking in the Nigerian [Trovan] study, it counts as a case of exploitation." Id. Macklin's conclusion lends support to the fact that the New York court's finding with respect to the merits of the plaintiffs' ATS claim was incorrect. See supra Part II.A (discussing the Trovan Case).

${ }^{170}$ See supra notes 157-60 and accompanying text (describing the ICCPR and its binding effects); see also Sosa, 542 U.S. at 735 (finding that, although the ICCPR "was not self-executing," it "does bind the United States as a matter of international law").

${ }^{171}$ See supra notes 133-39 and accompanying text (noting the findings of the Nuremberg Trials and their applicability to the United States). 
foreign countries. ${ }^{172}$ Furthermore, the requirement appears in the binding international law document resulting from the $\mathrm{CHRB},{ }^{173}$ is recognized by at least fifteen states in the specific form outlined in the Declaration of Helsinki, ${ }^{174}$ and is recognized by private actors in both the CIOMS $^{175}$ and the ICH guidelines. ${ }^{176}$ Taken together, these instruments demonstrate a universal condemnation of informed consent violations.

Although some consider informed consent to be a component of customary international law, ${ }^{177}$ one opposing view claims that the lack of "widespread [or] consistent state practice" refutes the existence of such a right. ${ }^{178}$ If successful, this criticism would challenge a finding of informed consent as customary international law, which is actionable under the ATS. ${ }^{179}$ In response to this criticism, it is sufficient to note the distinction between two concepts: a state's demonstration of its respect for an existing norm, and the existence of the norm itself. In other words, individual states' violations of a norm should not negate per se the existence of the norm. The fact that individual nationstates may refuse to abide by customary norms requiring informed consent cannot be used to refute the clear mandate for informed consent established in the international instruments governing medical experimentation. ${ }^{180}$

${ }^{172}$ See supra notes 35-39 and accompanying text (discussing FDA requirements for research that will later support an application to market a drug in the United States).

${ }^{173}$ See supra notes 161-63 and accompanying text (outlining the requirements placed on the EU member states that have ratified the CHRB).

${ }^{174}$ See supra note 144 (demonstrating the widespread acceptance and codification of the Declaration of Helsinki). The majority of these additional states are not EU member states.

${ }^{175}$ See supra notes $146-51$ and accompanying text (laying out the CIOMS agreement).

${ }^{176}$ See supra notes 152-54 and accompanying text (presenting the ICH guidelines).

177 See Meier, supra note 40, at 535 (citing authorities arguing that the requirement of free and informed consent binds all nations, even without a multilateral treaty).

${ }^{178}$ Id. But see supra note 91 (arguing that informed consent meets the state practice standard).

${ }^{179}$ See supra note 125 and accompanying text (noting the "definable, universal and obligatory" standard).

${ }^{180}$ See Fidler, supra note 159, at 337 (distinguishing the "right to free consent" from its implementation). 


\section{Informed Consent is Definable}

While instruments vary in their specific descriptions of informed consent, most generally, the doctrine protects an individual's rights to bodily integrity and to make choices about what can and cannot be done to her person. ${ }^{181}$ Adequate consent requires that investigators inform study participants about the risks and benefits attendant to a proposed intervention in a clinical trial and that their choice to participate (and, in many cases, to withdraw) remains voluntary and mutable. ${ }^{182}$ This definition is consistent across instruments describing a principle of consent. ${ }^{183}$ The principle of informed consent is therefore so broadly accepted and specifically understood to require these minimum elements that the concept of informed consent can be considered to have a universal understanding in the international context. $^{184}$

\section{The Norm of Informed Consent is Obligatory}

One criterion by which to judge the "obligatory" requirement for a customary norm of international law is the existence of binding law supporting the norm. International instruments create a binding requirement to obey informed consent. The ICCPR sets forth a requirement for informed consent in a treaty that is binding upon the United States. ${ }^{185}$ The CHRB creates an analogous obligation on members of the EU. ${ }^{186}$ A second element by which the Sosa Court judged the obligatory nature of a potential tort duty was the existence of common law recognition of a right of action for the violation. ${ }^{187}$ There is extensive U.S. common law recognition of a right of action

${ }^{181}$ Kevin M. King, Note, A Proposal for the Effective International Regulation of Biomedical Research Involving Human Subjects, 34 STAN. J. INT'L L. 163, 174 (1998) (arguing that informed consent upholds the "right to bodily integrity" and permits one "to exercise sovereignty over her body").

${ }^{182}$ Id. at $190-97$.

${ }^{183}$ See supra notes 138, 141, 153 \& 162 (quoting these or similar elements in the Nuremberg Code, Declaration of Helsinki, ICH guidelines, and CHRB); see also supra note 148 and accompanying text (showing the acknowledgment of the Declaration of Helsinki's definition in the CIOMS).

${ }^{184}$ See supra Part III.A (detailing guidelines in international instruments providing for informed consent in research); see also supra note 169 and accompanying text (discussing the universal understanding of this norm and its minimum elements).

${ }^{185}$ See supra notes 157-60 (referencing the content and scope of the ICCPR).

${ }^{186}$ See supra notes 161-66 (discussing the CHRB).

${ }^{187}$ See supra notes $127-30$ and accompanying text (explaining the common law recognition requirement). 
for failure to obtain informed consent, ${ }^{188}$ which further supports a finding that such a violation merits a private right of action under the federal common law. Similarly, the dismissal of claims based on forum non conveniens suggests a belief that another forum will recognize a cause of action and permit litigation of the claim. ${ }^{189}$

\section{A Norm of Informed Consent Should Be Recognized Under the Federal Common Law}

The Sosa decision continues to generate much controversy over its potential narrowing of the ATS's applicability. ${ }^{190}$ In that decision, however, the Supreme Court was careful not to overrule a recent history of expansive interpretation under the ATS. In fact, the Court acknowledged and relied on Filartiga, a case that is considered to be the

${ }^{188}$ There is a rich literature discussing the absolute requirement for informed consent in the United States. See Schloendorff v. Soc'y of N.Y. Hosp., 105 N.E. 92, 92 (N.Y. 1914) (maintaining a requirement for informed consent in any intervention taken on a person), overruled on other grounds by Bing v. Thunig, 143 N.E.2d 3, 9 (N.Y. 1957). With respect to clinical trials conducted abroad, U.S. common law supports the norms indicated in the Nuremberg Code. See generally Nuremberg Code, supra note 134, and accompanying text (describing the case of United States $v$. Brandt); United States v. Stanley, 483 U.S. 669, 708 (1987) (O'Connor, J., dissenting) (noting that the majority's reliance on "a judicially crafted rule [of governmental immunity] should [not] insulate from liability the involuntary and unknowing human experimentation alleged"); id. at 687 (Brennan, J., dissenting) (arguing that the legal question of immunity considered by the majority ought not abdicate the moral and legal imperative against unknowing human subjects). The dissenters argued that the majority's decision, resting on judicially created immunity, inappropriately ignored the absolute requirements of the Nuremberg Code. FDA regulations also create a legal requirement to uphold minimum standards in the Declaration of Helsinki. See supra notes 39, 14045 (outlining the requirements of the Declaration of Helsinki and its acceptance by the FDA in foreign research).

${ }^{189}$ The forum non conveniens challenges faced by litigants attempting to use the ATS in the United States suggest wide applicability of the informed consent norm in foreign common law, with an indication that there are alternative fora in which these rights would be recognized. See Jolyon Ford \& George Tomossy, Clinical Trials in Developing Countries: The Plaintiff's Challenge, LAW, SOC. JUST. \& GLOBAL DEV. § 3.3, June 4, 2004, http://www2.warwick.ac.uk/fac/soc/law/elj/lgd/2004_1/ford/ (discussing the factors a litigant may consider when bringing a lawsuit abroad rather than in the country where the clinical trial took place, but also noting the perceived corruptness of foreign tribunals). The inadequacy of alternative forums, apart from corruption or procedural infirmities, does not negate legal recognition of claims; rather it supports the need for additional recognition in the U.S. legal system and, more specifically, in U.S. federal common law.

${ }^{190}$ See Kontorovich, supra note 12, at 115 ("The 'door' that Sosa leaves 'ajar subject to vigilant doorkeeping' has nothing behind it." (quoting Sosa v. Alvarez-Machain, 542 U.S. 692, $729(2004)))$. 
starting point of this expansive interpretation. ${ }^{191}$ Though the Court cautioned that the ATS was not intended to create a private right of action for any alleged violation of international law, the narrow holding of Sosa was this: one cannot allege that any unauthorized detention of minimal duration rises to the level of concern which merits recovery under the ATS. Certainly a more specific and more serious harm than this results from failure to obtain consent for the repeated intrusions upon one's body that occur in the context of clinical research. The requirement for informed consent found in all identifiable discussions of research subjects protections evidences an international demand for respect of this principle. Informed consent in the conduct of clinical trials has unquestionably reached the status of customary international law that is actionable under the ATS, as required by the "definable, universal and obligatory" standard of the Sosa Court. ${ }^{192}$ Well-defined principles of informed consent therefore provide a reasonable basis upon which to allege an actionable claim for recovery under the ATS when harm results from a failure to follow customary international law governing consent. Even after Sosa, the specificity of such norms and the magnitude of their importance demand nothing less.

191 See supra Part II.B (detailing the holding in Filartiga v. Pena-Irala, 630 F.2d 876 (2d Cir. 1980), and its interpretation under Sosa).

${ }^{192}$ Sosa v. Alvarez-Machain, 542 U.S. 692, 732 (2004). In its opinion, the Sosa Court also referred to the principles of international law from the Restatement (Third) of Foreign Relations Law, which leave room for a finding of a customary international norm even when it is not unanimously agreed upon. Id. In notes to section 103 of the $R e-$ statement, commentators indicate that declarations of international organizations can also "provide important evidence of law," adding that " $[\mathrm{t}]$ he evidentiary value of such a resolution is high if it is adopted by consensus or by virtually unanimous vote of an organization of universal membership such as the United Nations or its Specialized Agencies." See Restatement (ThIRD) OF Foreign ReLations LaW § 103 reporter's note 2 (1987) (adding weight to UN agreements such as the ICCPR that mandate consent in clinical experimentation); see also Fidler, supra note 159, at 337 (asserting that the right to informed consent exists, despite some developing countries' difficulties implementing it); Jonathan Todres, Can Research Subjects of Clinical Trials in Developing Countries Sue Physician-Investigators for Human Rights Violations?, 16 N.Y.L. SCH. J. Hum. RTS. 737, 740 (2000) (exploring viability of ATS claims in the pre-Sosa era). But see Meier, supra note 40, at $535 \&$ n.141 (contesting consistent applicability of the norm). With only one case under the ATS in the United States, this is an area ripe for a decisive authority on the status of international law governing informed consent. The increasing recognition of the harms created by unchecked medical experimentation demands an official determination on accountability for violations, contrary to the position taken by the Southern District of New York in the Trovan Case. See supra Part II.A (discussing the Trovan Case and its outcome). 


\section{Nonsubstantive Considerations in ATS Litigation}

The Sosa decision is important because it clarifies the substantive requirements of an ATS action. Beyond a determination of what constitutes an actionable claim under the ATS, however, plaintiffs must successfully navigate several other components of ATS litigation: the state action requirement, procedural barriers such as forum non conveniens and the political question doctrine, and evidentiary burdens. While this Comment will not attempt a comprehensive discussion of each element, they are briefly discussed here for completeness.

\section{State Action Requirement}

State action is generally considered a prerequisite for any action under the ATS because the law of nations governs relations between nation-states. ${ }^{193}$ In litigating alleged violations of international law, plaintiffs may demonstrate state action through one of the traditional tests; alternatively, they may argue that the state action requirement should be suspended and that the statute should be applied to private actions so egregious that they demand a response. Traditionally, courts have applied one of four tests when determining whether the state action requirement has been met. In the "joint action test," plaintiffs must demonstrate that the private actor acted "in concert" with the state. ${ }^{194}$ The "symbiotic relationship test" asks whether the state has "'so far insinuated itself into a position of interdependence' with a private party that 'it must be recognized as a joint participant in the challenged activity.", "195 The "nexus test" requires that the state have "significant involvement and actual participation" in the action of the private actor, such that it could no longer be considered private conduct. ${ }^{196}$ The fourth test, "public function," asks whether the action typically is one reserved for the state. ${ }^{197}$ Based on these definitions, claimants bringing an action under the ATS for alleged violations of human subjects norms that require informed consent likely would be able to use the symbiotic, public function, and nexus tests to argue that state action has taken place.

${ }^{193}$ See supra notes 97-99 and accompanying text (discussing the Sosa Court's restatement of this interpretation of the law of nations).

${ }^{194}$ Beanal v. Freeport-McMoran, Inc., 969 F. Supp. 362, 379 (E.D. La. 1997).

${ }^{195} I d$. at 378 (quoting Burton v. Wilmington Parking Auth., 365 U.S. 715, 725 (1961)).

${ }^{196}$ Beanal, 969 F. Supp. at 377.

${ }^{197}$ Id. at 379. 
Under the symbiotic test, analysis probably would proceed as follows: because developing countries receive significant benefits from research conducted by private corporations, which bring needed medical services in the context of medical experimentation, foreign governments can become interdependent with the private actor. In other words, foreign governments rely on researchers to fill an access gap, ${ }^{198}$ while researchers rely on foreign governments for speedy access to data. This interdependence often permits researchers to offer substandard care to human subjects, so long as the researchers remain in the foreign country to provide medical services to its population. ${ }^{199}$

Plaintiffs also could argue that the state action requirement is met through the public function test. When conducting clinical trials in developing countries, researchers, who are private actors, become the means through which governments provide healthcare to their citizens, especially during epidemics. Managing the public's health typically and traditionally is a function reserved for a state's government and regulatory oversight. As such, researchers' provision of that care, where government has failed to do so, constitutes state action.

As a third way to meet the state action requirement, plaintiffs should consider the FDA's ethical requirements for foreign research as a potential route to satisfaction of the nexus test. ${ }^{200}$ The FDA requirements serve as a representation made by the United States to other countries regarding the expected level of research subject protections. These FDA requirements are relevant to a discussion of state action because the United States may develop a sufficiently close nexus with a private actor through that actor's placement of a protocol through FDA channels prior to that actor's departure to a foreign nation to conduct research. If the FDA supervises the research, then it arguably has become a participant. Even if the private actor chooses not to submit research under FDA supervision, the FDA nonetheless makes an official representation to other countries that the research will be conducted under a certain standard of care. Either approach

${ }^{198}$ See supra note 28 (defining and discussing the "access gap").

199 See supra Part I.A-B (commenting on the reciprocal utility between private actors and developing countries that would support such interdependence); see also MACKLIN, supra note 19, at 6-13 (discussing the "unquestionable gains" of researchers and the health needs of developing countries as related factors that motivate research abroad). See generally THE CONSTANT GARDENER, supra note 4 (depicting dramatically the idea that foreign governments often sanction, and even encourage, research on unknowing victims).

${ }^{200}$ See supra Part I.A (listing the expected ethical norms governing foreign research used to support a new drug application under FDA regulations). 
would seem to satisfy the traditional standards of the nexus test for state action.

Alternatively, plaintiffs could argue that a finding of state action is not necessary, because the alleged conduct is so abhorrent that it warrants universal condemnation. In Kadic v. Karadzic, a landmark case following Filartiga, the Second Circuit expanded liability under the ATS to nonstate actors, on the grounds that there is a "substantial body of law ... that renders private individuals liable for some international law violations." ${ }^{201}$ The court based its decision on Restatement provisions suggesting that actions of "universal concern" should be actionable. ${ }^{202}$

While Sosa limits the scope of the ATS, its holding with respect to the state action requirement does not substantively change existing law. The deference of the Sosa Court to Restatement formulations governing international law suggests that the Court would agree that actions of "universal concern" would remain actionable. ${ }^{203}$ Informed consent falls into the category of actions considered to be of "universal concern." "Certain crimes are simply so horrific that, since Nuremberg, they have been universally condemned. The horror of World War II led to a consensus that no one-no nation, person, or other legal entity-should ever be allowed to commit such crimes with impunity again.” ${ }^{205}$ Beginning with the findings at Nuremberg, ${ }^{206}$ the re-

20170 F.3d 232, 239 (2d Cir. 1995) (finding that genocide and torture by a private actor self-proclaimed as a state qualified under the ATS). But see Tel-Oren v. Libyan Arab Republic, 726 F.2d 774 (D.C. Cir. 1984) (declining to extend liability to the Palestine Liberation Organization (PLO) for various terrorist actions, including murder and torture).

${ }^{202}$ Kadic, 70 F.3d at 240 (citing Restatement (ThIRD) OF FOREIGN RELAtions LAW $\S \S 404,702$ ) (“[I]nternational law . . permits states to establish appropriate civil remedies (for offenses of 'universal concern') ... such as tort actions authorized by the Alien Tort Act.").

${ }^{203}$ See supra note 192 (discussing the Sosa Court's reference to Restatement principles describing acts that are widely accepted as violations and are universally condemned).

${ }^{204}$ See RESTATEMENT (THIRD) OF FOREIGN RELATIONS LAW $\$ 404 \mathrm{cmt}$. a ("Universal jurisdiction over the specified offenses is a result of universal condemnation of those activities and general interest in cooperating to suppress them, as reflected in widely accepted international agreements and resolutions of international organizations.").

${ }^{205}$ Londis, supra note 87, at 167 ; see also supra notes $169-76$ and accompanying text (noting that violations of informed consent are indisputably exploitative and universally condemned).

${ }^{206}$ See Fidler, supra note 159, at 337 (reaffirming the significance of the Nuremberg Code in ending the atrocities of WWII and establishing the "right to free consent"). 
quirement of informed consent has been consistently upheld and specifically applied. Thus, even after Sosa, private actors would likely meet the state action exemption criteria necessary to be found liable under the ATS on these grounds.

\section{Forum Non Conveniens}

The most discussed obstacle for those initiating an ATS action remains dismissal for forum non conveniens. But plaintiffs from developing countries often lack a legitimate forum in which to litigate their claims. International fora designed to protect human rights will not hear these claims. "[E]ven if the norm requiring informed consent to medical experimentation has some status and certain content under international law, its breach is likely to be unenforceable in [International Human Rights Litigation (IHRL)] fora, since most violations will be by non-state actors." ${ }^{207}$ Litigation under the ATS, however, will sometimes suspend this state action requirement. ${ }^{208}$ Despite the fact that the ATS provides a more viable option for recovery, claims brought in a United States court are often dismissed, thereby requiring the plaintiffs to demonstrate the lack of a suitable alternative forum in order to maintain their action. The plaintiffs in the Trovan Case were twice dismissed on these grounds, with instructions to return only if they could not find adequate consideration of their claims in another forum. ${ }^{209}$ Nonetheless, courts will deem a forum inadequate only when it is "so clearly ... unsatisfactory that it is no remedy at all." ${ }^{210}$ Plaintiffs may attempt to base the inadequacy of an alternative forum on the grounds that the foreign forum is politically influenced to the point of corruption, lacks sufficient assets to afford an adequate remedy, or cannot provide an opportunity for fair judg-

${ }^{207}$ Ford \& Tomossy, supra note $189, \S 3.2$ (discussing the lack of suitable international fora, which limits individuals' claims to actions taken by a state). Even if individuals can successfully argue the presence of state action, they still are unlikely to find suitable compensation via international human rights litigation fora, such as that provided by the First Optional Protocol to the ICCPR. See id. ("[A]s only the state holds duties under the ICCPR, the action (under the First Optional Protocol) would not be useful against a corporate trial sponsor and would require that the subject's own state ... was sufficiently involved in the drug trial.”). tions).

${ }^{208}$ See supra Part III.D.1 (outlining the state action requirement and its excep-

${ }^{209}$ See Trovan Case, No. 01 CIV 8118, 2005 WL 1870811 (S.D.N.Y. Aug. 9, 2005), at *18 (conditioning the forum non conveniens dismissal on the expectation of action by the alternative forum in Nigeria).

${ }^{210}$ Piper Aircraft Co. v. Reyno, 454 U.S. 235, 254 (1981). 
ment because of the strong local presence of the defendant. ${ }^{211}$ Given the strong involvement of foreign governments in encouraging research abroad, courts may be more willing to consider these arguments when judging the adequacy of the alternative forum abroad. ${ }^{21}$

\title{
3. Political Question Doctrine
}

Courts' recognition of the political question doctrine generates a second procedural obstacle for individuals seeking application of the ATS in United States courts. If a court determines that the resolution of a case involves answering a political question, it will refuse to hear the case. The U.S. Supreme Court in Baker v. Carr $^{213}$ established the standard for judging whether a political question exists:

\begin{abstract}
A given suit may present a political question if: (1) the matter is constitutionally committed to a coordinate branch of government; (2) no "judicially discoverable and manageable standards" exist to guide the court's analysis; (3) it is impossible to decide the case without making an initial policy determination that should rightfully be made by a separate branch; (4) deciding the case would express "a lack of respect" to a coordinate branch of government; (5) there is "an unusual need for unquestioning adherence to a political decision already made"; or (6) the potential embarrassment to the U.S. government could arise as a result of "multifarious pronouncements by various departments on one question." 214
\end{abstract}

The Kadic court announced that Filartiga essentially eliminated dismissal based on the first three standards by establishing judicially manageable standards with respect to international law. ${ }^{215}$ That court also stated that factors four through six presented a viable barrier "only if judicial resolution of a question would contradict prior decisions taken by a political branch in those limited contexts where such contradiction would seriously interfere with important governmental interests." ${ }^{216}$ Londis indicates that, in the ATS context, the "critical

${ }^{211}$ See Ford \& Tomossy, supra note $189, \S 3.3$ (discussing these possibilities in the context of the Trovan Case).

${ }^{212}$ Indeed, in the Trovan Case, an initial dismissal on the grounds of forum non conveniens was remanded for consideration based on similar litigation which had not received an adequate response. See Trovan Case, 2005 WL 1870811, at *5 (remanding for reconsideration of a suitable alternative forum).

213369 U.S. 186 (1962).

${ }^{214}$ Londis, supra note 87, at 185-86 (summarizing the findings in Baker).

${ }^{215}$ See Kadic v. Karadzic, 70 F.3d 232, 249 (2d Cir. 1995) (applying the holding of Filartiga to the first three factors of justiciability).

${ }^{216} I d$. 
inquiry involves whether a given ruling would upset, embarrass, or enrage a sovereign nation, or embarrass the executive by contradicting or undermining its foreign policy statements." ${ }^{217}$ It would be difficult for a defendant to win dismissal on the basis of the political question doctrine because the executive branch vests authority in the FDA to determine the standards under which research should be conducted. ${ }^{218}$ If these standards are violated, it cannot be contradictory for the executive to hold the violators accountable. Similarly, the United States should not be concerned with upsetting a sovereign nation by enforcing its own standards for foreign research.

\section{Evidentiary Burdens}

The Sosa decision reinforces the notion that the ATS is a jurisdictional statute with limited ability to create new federal common law. In addition to establishing jurisdiction, plaintiffs are still required to prove all elements of a traditional tort action to secure recovery. The law of nations suffices to demonstrate the duty element of a prima facie tort claim. A violation of the law of nations constitutes a breach of duty for the purposes of a tort action. Plaintiffs also carry the burden of demonstrating the remaining tort elements of causation and damages. Because of the general nature of international litigation, plaintiffs often face significant obstacles in meeting the evidentiary burden of demonstrating these two elements. ${ }^{219}$ While this should be an important concern for anyone attempting to litigate an ATS claim, plaintiffs involved in clinical trial litigation might find it slightly less difficult to obtain documentation that could establish the necessary elements to prove their case, given that companies who later wish to obtain approval for drug marketing in the United States will need to submit documentation related to their studies. ${ }^{220}$ Therefore, these

\footnotetext{
${ }^{217}$ Londis, supra note 87, at 186.

${ }^{218}$ See supra Part I (describing the FDA's ethical expectations for its acceptance of foreign research).

${ }_{219}$ See Todres, supra note 192, at 759-66 (discussing difficulties relating to cultural differences and reasonable investigator duties that may preclude the ability to demonstrate causation and damages). Poor or nonexistent record keeping may also prove to be a significant evidentiary hurdle to demonstrating elements of a tort action. See MACKLIN, supra note 19, at 100-01 ("[F]laws in procedural aspects-such as failure to keep proper records . . . - may not rise to the level of exploitation, [but] they are nevertheless unethical features of research involving human subjects.").

${ }^{220}$ See supra notes 14-19 and accompanying text (discussing the interaction between the FDA and investigators conducting research in developing countries).
} 
considerations should not alone discourage suits under the ATS for alleged human subjects abuses involving inadequate consent.

\section{CONCLUSION}

Human dignity and bodily integrity remain fundamental human rights. These rights attain special meaning in the context of research involving human subjects, where the possibility of exploitation exists. Recognizing the potential vulnerability of human subjects, the international community goes further than forming broad aspirations about ethical conduct in research. International law specifically condemns actions done in the name of medical experimentation that deny the individual's rights to self-determination and to make a truly informed decision about what happens with her body. However, inconsistent or nonexistent enforcement of international norms governing research involving human subjects undermines their legitimacy. Creating accountability for violations of norms concerning human subjects research is imperative in an environment that favors the continued globalization of biomedical research. The ATS, enacted to provide a location for adjudication of torts committed in violation of international law, provides a viable forum for recovery for those harmed in research conducted in violation of certain international norms.

Past human subjects who become ATS litigants can surmount traditional barriers to recovery under this statute. Reciprocal involvement by both domestic and foreign governments in human subjects research practices provides a source of state action, although legal precedent suggests that private actors might also be found responsible for violations of research ethics, irrespective of whether plaintiffs can prove state action. Because of the authority granted by the executive branch of the U.S. government to the FDA, the political question doctrine also is unlikely to create a significant barrier to ATS claims in U.S. courts. Plaintiffs attempting an ATS action do face significant challenges due to evidentiary burdens and a tendency toward forum non conveniens determinations. The former concern should not create a barrier to entry into a U.S. court on an ATS claim, though it may impact the likelihood of success on the merits; the latter can be overcome through the growing attention of the international community to the potential inadequacy of foreign tribunals that would otherwise hear these claims. 
The U.S. Supreme Court's decision in Sosa seemingly presents the most significant obstacle to using the ATS to recover for alleged violation of ethical mandates concerning medical experimentation. Nonetheless, careful examination of the discrete holding in Sosa, and of the international nature of informed consent, demonstrates that Sosa would not restrict claims based specifically on inadequate consent to research. Informed consent, in fact, offers the most basic of protections for human subjects involved in research; it is the mechanism by which investigators preserve a subject's dignity and demonstrate respect for the integrity of the human body. Numerous doctrines of binding international law describe a right to informed consent, and scholars confirm this principle's universal acceptance. The mandate for informed consent in human experimentation raises this principle to the level of a customary international norm, which deserves recognition under the federal common law-and correspondingly merits jurisdiction in U.S. courts under the ATS. Thus, even after the restrictions placed on the ATS's applicability following Sosa, this statute offers a much needed solution for successful protection of human subjects involved in medical experimentation. Although Sosa leaves the door to recovery under the ATS only narrowly ajar, informed consent easily passes through. 